\title{
Aid for Trade Flows and Wage Inequality in the Manufacturing Sector of Recipient-Countries
}

\author{
Sèna Kimm Gnangnon ${ }^{1+}$ \\ ${ }^{1}$ World Trade Organization, Switzerland
}

\begin{abstract}
This study contributes to the extant literature on the effectiveness of Aid for Trade (AfT) flows in recipient-countries by examining the effect of these resource flows on wage inequality in the recipientcountries' manufacturing sector. The analysis shows that AfT interventions help reduce wage inequality in the manufacturing sector of countries that have liberalized trade policies, enjoy greater trade openness, experience higher exports of labor-intensive manufacturing products, higher exports of low-skill-intensive manufacturing products, and greater exports of high-skill-intensive manufacturing products. Additionally, AfT interventions contribute to moderating the negative effect of export product concentration (e.g., on primary products) on wage inequality in the manufacturing sector. Finally, AfT flows reduce wage inequality in the manufacturing sector of countries that import manufacturing products (including machinery and transport equipment goods) or enjoy wider multilateral trade liberalization.
\end{abstract}

Keywords: Aid for Trade; Wage inequality in the manufacturing sector; Developing countries

JEL Classifications: F35, F13, F14, J3

Received 16 February 2020, Revised 28 March 2020, Accepted 3 June 2020

\section{Introduction}

Several studies exist on the determinants of income inequality in developing countries. However, despite the relevance of development aid for developing countries, few studies (e.g., Berrittella, 2017; Bjørnskov, 2010; Bourguignon et al., 2009; Calderon et al., 2009; Chao et al., 2010; Herzer and Nunnenkamp, 2012; Layton and Lielson, 2008; Pham, 2015; Younsi et al., 2019) have considered its effect on income inequality. Some have reported that development aid can widen income inequality in recipient-countries (e.g., Bjørnskov, 2010; Herzer \& Nunnenkamp, 2012; Pham, 2015; Younsi et al., 2019), while others found a weak effect (e.g., Calderon et al., 2009; Layton \& Lielson, 2008). Bourguignon et al. (2009) noted that development aid improves equality. Several studies have focused on the determinants of wage inequality, in the manufacturing sector as well, in developing countries. However, few studies ${ }^{1)}$ have considered the effect of development aid flows on wage inequality in the manufacturing sector 
of recipient-countries, and even fewer on the effect of Aid for Trade (AfT) flows, which represents part of development aid dedicated to the development of the trade sector in developing countries, on wage inequality in the manufacturing sector of recipient-countries. ${ }^{2}$ ) The desire of developing countries to secure greater financial resources to participate in international trade has underpinned the launch of the AfT Initiative by the Members of the World Trade Organization (WTO) at the 2005 WTO Hong Kong Ministerial Conference. The purpose of this Initiative is contained in Paragraph 57 of the Hong Kong Ministerial Declaration (WTO, 2005), which states "Aid for Trade should aim to help developing countries, particularly LDCs, to build the supply side capacity and trade-related infrastructure that they need to assist them to implement and benefit from WTO Agreements and more broadly to expand their trade." Yet, the original intent of WTO members when launching the AfT Initiative was not to influence wages in the recipient-countries, including wages in the manufacturing sector, and thus wage inequality in this sector. However, AfT flows can genuinely affect wage inequality in the manufacturing sector of recipient-countries through its effects on several economic features of these countries, including trade policy (e.g., Gnangnon, 2018a), manufacturing exports (e.g., Ghimire et al., 2013; Gnangnon, 2018c, Hühne et al., 2014a), and export product diversification (e.g., Gnangnon, 2019b, 2019c; Kim, 2019).

This study contributes to the literature on the AfT effectiveness by exploring the effect of AfT flows on wage inequality in the manufacturing sector through these various channels. A sample of 65 AfT recipient-countries were analyzed over 1996-2016. The empirical findings showed that all these factors are responsible for the effect of AfT flows on wage inequality in the manufacturing sector of recipient-countries. This study additionally shows that manufacturing imports (e.g., imports of machinery and transport equipment) and the extent of multilateral trade liberalization highly influence the effect of AfT interventions on wage inequality in the manufacturing sector of recipient-countries.

The study is presented as follows. Section 2 provides a theoretical discussion on how AfT flows can affect wage inequality in the manufacturing sector of developing countries through these channels. Section 3 presents the model to empirically test the issue, and section 4 presents the data analysis. Section 5 discusses the appropriate econometric method for the empirical analysis, section 6 interprets the empirical outcomes, and section 7 concludes.

1) One of these rare studies is that of Chao et al. (2010), who have shown that an increase in foreign aid adversely affects national welfare and widens the wage inequality between skilled and unskilled workers.

2) Despite the important but still growing literature on the effectiveness of AfT flows (e.g., Cadot et al., 2014; Gnangnon, 2020a; OECD-WTO, 2017), there is to the best of our knowledge, no study on the effect of AfT flows on wage inequality in the manufacturing sector. 


\section{Theoretical Discussion}

This section discusses various channels through which AfT flows can affect wage inequality in the manufacturing sector of recipient-countries. These channels include trade policy liberalization (and trade openness), inward foreign direct investment (FDI), export of manufacturing products (and export product diversification). Each of these channels is subsequently discussed.

\section{A. Effect of AfT flows on wage inequality through trade policy liberalization (or trade openness)}

Gnangnon (2018a) empirically demonstrated that AfT flows are associated with greater trade policy liberalization in recipient-countries. Therefore, we hypothesize that the effect of AfT flows on wage inequality in the manufacturing sector of recipient-countries depends on the extent to which trade policy affects wage inequality. A literature review is presented on the effect of trade liberalization (or trade openness) on wage inequality in the manufacturing sector of developing countries, and how AfT interventions affect wage inequality in the manufacturing sector through the trade policy channel, is discussed.

Studies have examined the effect of trade liberalization on wages inequality in developing countries from different perspectives, starting from the standard Heckscher-Ohlin (HO) and Stolper-Samuelson (S-S) theories. The HO theory is based on restrictive assumptions, including perfect competition, perfect labor, capital mobility in the short term, trade in final goods, and fixed technology. The S-S theory relates factor prices to the changes in relative prices induced by trade. These theories predict that developing countries that liberalize their trade regimes (or open-up their economies to international trade), and thus experience lower trade costs, enjoy reduction in wage inequality between skilled and unskilled labor. This is because these countries are assumed to be relatively rich in unskilled labor, and therefore specialize in unskilled labor-intensive goods. Through liberalization, these countries enjoy higher exports and prices of unskilled labor-intensive products, which lead to increased demand and wages of unskilled labor relative to skilled labor. Therefore, wage inequality between skilled and unskilled workers would decline. In other words, when a developing country integrates into the world trade market, the skill premium (i.e., the wage differential between unskilled and skilled workers) and wage inequality will decline. Some studies have supported this theoretical prediction for the manufacturing sector. Rose (1987) argued theoretically that regulatory protectionism generates rents and higher wage premiums in the presence of workers' bargaining power. These wage premiums are reduced or totally eliminated as trade barriers are partially or completely removed, thus making trade liberalization negatively associated with wage inequality. This is particularly the case because unskilled workers' relative income deteriorate if unskilled labor-intensive sectors experience 
relatively higher tariffs before the trade reforms. Studies by Revenga (1997) for Mexico, and Ghazali (2011) for Tunisia showed that trade liberalization reduced the rents captured by skilled labor, and hence reduced the wage inequality between skilled and unskilled labor. Other studies ${ }^{3}$ ) have not confirmed the theoretical prediction, that is, trade liberalization (or trade openness) is associated with lower wage inequality. Instead, these studies found that several developing countries experienced a rise in the wage inequality, despite integration into the global market (e.g., Goldberg \& Pavcnik, 2004; 2007). Specifically, few studies have reported a positive association between trade policy protection and wage inequality (measured by industry wage premiums) in the manufacturing sector in developing counties. For example, Currie and Harrison (1997) theoretically and empirically demonstrated that trade reforms led to significant employment losses for exporters and highly affected firms (although, on average, employment in the private sector manufacturing firms was unaffected). Simultaneously, low-paid workers were hired by parastatals. Feliciano (2001), Attanasio et al. (2004), Goldberg and Pavcnik (2005), Sen (2008), and Anwar and Sun (2012) explained the positive effect of trade reforms on wage inequality (between skilled workers and unskilled workers) by the significant effect of trade reforms on industries highly intensive in unskilled labour. Thus, by increasing competition and productivity, $\left.{ }^{4}\right)$ trade liberalization led to decreased goods price of those unskilled labor-intensive industries, a higher demand for skilled workers than unskilled workers, and a decline in the wages of unskilled labor. These factors led to widened wage inequality between skilled and unskilled workers (Anwar \& Sun, 2012; Galiani et al., 2003; Hanson \& Harrison, 1999; Mishra \& Kumar, 2005). Chaudhuri and Yabuuchi (2007) emphasized the rise in wage inequality when import tariffs on low-skilled manufacturing sector in the presence of labor market imperfections were lowered.

Different other theoretical perspectives5) (that received empirical support) emerged to reconcile the real-world evidence and the theoretical predictions of the Heckscher-Ohlin-Samuelson (HOS).

Rise in wage inequality between low-skilled and high-skilled workers is explained by Feenstra and Hanson (1996, 1997), who stressed on the role of intermediate products that can be imported (i.e., the "outsourcing"). Feenstra and Hanson (1996) developed a model in which highly intensive activities in unskilled workers are outsourced from the North to the South, the latter being considered as a relatively skill-poor country and where low-skilled labor is comparatively

3) Goldberg and Pavcnik (2007) provided a literature review of the studies concerning the effect of trade liberalization on wages and inequality in developing countries.

4) This aligns with the theoretical argument that productivity enhancement at the firm level due to the greater competition induced by trade liberalization can translate into higher industry wages (e.g., Helpman \& Krugman, 1989).

5) Harrison et al. (2011) provided a survey on many mechanisms through which trade can affect and usually results in higher income inequality. Institutional factors, including rigidities in the labor market, represent another perspective on the relationship between trade and wage inequality (e.g., Topalova, 2010). 
cheaper (see also Feenstra \& Hanson, 2001). The North would experience reduced wages of low-skilled workers relative to wages of high-skilled workers, due in particular to lower demand for low-skilled labor in the North. This leads to a rise in the wage inequality between skilled and unskilled workers. However, the outsourcing of low-skilled production work from the North to the South corresponds to a high-skilled production work in the South (i.e., developing countries). This leads to a rise in the demand for skilled labor in developing countries, and hence, higher wage inequality. Ebenstein et al. (2014) reported a positive effect of trade and offshoring on wage inequality for American workers.

Another perspective has relaxed the fixed technology assumption in the HOS prediction, and considered technology as endogenous for a country. Greater trade liberalization (or trade openness) could change a country's technological orientation (e.g., Wood, 1995) through higher imports of goods embedded with advanced knowledge and technology and through capital inflows (e.g., Acemoglu, 2003). Consequently, the technology changes induced by greater participation in international trade will increase the demand for skilled labor rather than for unskilled (or low-skilled) labor. Wages for high-skilled labor would increase relatively to that of unskilled (or low-skilled) labor, thereby leading to widened wage inequality between skilled and unskilled labor. This is referred to as the skilled-bias technological change (SBTC) argument to explain the increasing wage inequality between skilled and unskilled labor. While several studies $^{6)}$ have provided empirical support for the SBTC theory7) for developed economies (see, e.g., Lee \& Wie, 2015) some have reported a positive association between technological changes and wage inequality in developing countries, including Berman et al. (2005) and Kijima (2006) for India; Bustos (2011) for Argentina; Chen et al. (2010) for China; Harrison (2008) for Brazil and India; Hahn and Choi (2017) for Korea, and Lee and Wie (2015) for Indonesia, and Martorano and Sanfilippo (2015) for Asian countries. Additionally, Berman and Machin (2000) observed that skill biased technology transfer contributes to the rise in the demand for skilled workers in middle-income countries, but less so in low-income countries. Gourdon (2011) provided empirical evidence that South-South trade liberalization has led to a greater bias of technological change toward skill-intensive sectors than North-South trade liberalization and to a higher wage inequality in developing countries, with this effect being more important in low-income countries. Zhu and Trefler (2005) showed that technological catch-up by developing countries led to the migration of the production of the least skill-intensive Northern goods to developing countries, where these goods have become the most skill-intensive products. These have widened the wage inequality in both developing and developed countries.

6) Nevertheless, Card and DiNardo (2002) proposed that nonmarket factors (e.g., minimum wage and labor unions) are more important than technological changes in explaining rising wage inequality. They have considered technological change as an episodic event, and not a secular trend.

7) Feenstra and Hanson (1999) showed that offshoring (by 25\%) and technological change (by 30\%) explained the increase in the relative wage of nonproduction workers in the United States over 1979-1990. 
The South-South trade argument explains wage inequalities in developing countries, given the substantial increase in South-South trade since the 1980s. The emergence of developing countries, such as China, with a large pool of unskilled labor force has increased competition among developing countries in the context of South-South trade and led to a reduction in the prices of products and low-skilled labor rewards, which has led to a wide wage gap between skilled and unskilled workers in developing countries. Davis (1996) developed a theoretical framework on the effect of trade liberalization on rewards from factors within different countries with similar endowments and emphasized the need for differentiating among various developing countries to obtain clear results on the wages effects of trade liberalization; thus, the key is how a country has been positioned among other countries within its own cone of diversification. Gourdon (2011) empirically proved that trade liberalization in the context of South-South trade has contributed to greater wage inequality in middle-income, developing countries than North-South trade liberalization.

Based on this literature review, we postulate that the effect of AfT flows on wage inequality depends on how trade policy affects wage inequality. Despite the lack of consensus in the literature, one might conclude that trade policy liberalization results in greater wage inequality in the manufacturing sector of developing countries, even though this remains an empirical issue. We postulate that as AfT flows are associated with greater trade policy liberalization, these inflows result in higher (lower) wage inequality in the manufacturing sector of developing countries, depending on whether trade policy liberalization induces higher (lower) wage inequality in this sector. Simultaneously, AfT interventions address the structural constraints ${ }^{8)}$ that prevent recipient-countries from genuinely participating in, and taking fair advantages of international trade. Thus, these inflows not only enhance competitiveness of the existing small and medium enterprise (SMEs) but also promote the emergence of new SMEs, thereby developing self-employment and allowing previously unemployed or underemployed workers to earn income (or wage). Given the large pool of less skilled unemployed workers in many developing countries, the employment generated by AfT flows (e.g., Gnangnon, 2018b; 2019a) reduces wage inequality between high-skilled and low-skilled workers, including in the context of greater trade policy liberalization. However, if thanks to greater trade liberalization AfT flows promote technological changes in recipient-countries, these resource inflows can eventually lead to a widening of wage inequality in the manufacturing sector of recipient-countries, considering the positive wage inequality effect of SBTC. On the other hand, AfT flows, in particular, AfT for trade policy and regulation, can help mitigate the adverse effect of trade-induced technological changes by compensating workers and firms for the social dislocation resulting

8) Structural constraints are addressed by including improvement of the business environment, better access to finance, and support for seizing opportunities in the international market (see ITC/WTO (2014); OECD/WTO (2015) and OECD/WTO (2019)). 
from increased competition associated with greater trade liberalization (e.g., OECD, 2010). In this scenario, AfT flows would be associated with lower wage inequality as countries further liberalize their trade regimes.

\section{B. Effect of AfT flows on wage inequality through exports, including manufacturing exports}

Studies examined the effect of international trade on wage inequality by relying on the heterogeneous firm trade model developed by Melitz (2003) and incorporating firms and workers' heterogeneity as well as labor market imperfections. In this study, wage inequality is refered to as the wage gap between exporters and nonexporters. For example, Egger and Kreickemeier (2009) developed a heterogeneous firm trade model where imperfections of the labor market are considered through a fair wage effort mechanism. This model considers that workers attach importance to receiving "fair wages," which depend on the economic success of their firm. Thus, workers expect to receive higher wages as their firms become more productive and profitable, so that in equilibrium, productive exporting firms would pay higher wages. Overall, in this study, wages differ from firm to firm and fuel wages inequality. Helpman et al. (2010) developed the Melitz-type model (see Melitz, 2003) by including searching and matching frictions as well as employer screening to explain the relationship between trade and wage inequality. In this setting, employees bargain for profit sharing because hiring costs prevent workers outside a firm from perfectly substituting for current employees. Therefore, ex-ante, workers are homogeneous, but benefit from a firm-specific ability bonus. The incentives for firms to screen workers arise from the complementarities between employees' abilities and the firm's productivity. Thus, highly productive exporting firms would strengthen their monitoring of workers and retain those workers with higher average ability. They would pay higher wages to those workers because it is costly to replace higher-ability employees. In this context, greater trade liberalization would incentivize highly productive firms to export and intensify their monitoring of workers. Therefore, exporting firms would pay higher wages than nonexporting firms because they are likely to have workforce with higher average ability.

In fact, exporter wage premium dates back to the seminal work by Bernard and Jensen (1995, 1997), which received strong empirical support9) in the literature. Bernard and Jensen (1997) considered the case of the United States in the 1980s and shown that the rise in wage inequality in the US manufacturing was because of the relative rise in the labor demand by exporting firms, which, compared with nonexporting firms, employ more highly skilled rather than lower-skilled workers. The rise in the wage inequality between skilled and low-skilled workers is due to the expansion of exporting firms, which demand a relatively more number

9) See, for example, Schank et al. (2007) for a literature review on this matter. 
of highly skilled than low-skilled workers. This increasing wage inequality effect owing to expansion of manufacturing exports can be further strengthened if exporting firms compensate skill groups differently compared with domestic firms, and particularly if they pay a higher export wage premium to highly skilled than low-skilled workers. Some studies have also shown that employment premium ${ }^{10)}$ is associated with exporting because exporting firms usually have a large workforce than nonexporting firms (e.g., Bernard \& Jensen, 1999, Brambilla et al., 2015; Serti et al., 2010). Additionally, exporting firms reward their workers with higher wages (including through a premium, see Brambilla et al., 2015), especially if they enjoy higher profits (e.g., Brambilla et al., 2012; Amiti \& Davis, 2012; Baumgarten, 2013). Kong et al. (2018) examined Chinese firms and found that higher exports are positively associated with higher average wages of firms. However, only top managers, including those having overseas work experience, enjoy a wage premium, and only employees with high educational level receive significant wage premiums, while other employees do not. Matthee et al. (2017) concluded that a large wage inequality exists among exporting firms in the manufacturing sector of South Africa (even relatively among nonexporting firms), However, this inequality is not explained by exporting but rather by the firms' characteristics in the export market. The wage inequality, associated with exporting activities or various types of employment between these activities, - - within different levels of skills, i.e., between highly skilled workers and low-skilled workers - has been illustrated by Alvarez and López (2005), Bustos (2011), Klein et al. (2013), Tsou et al. (2006), and Van Biesebroeck (2005). Bas (2012) used data of Chilean firms operating in the manufacturing sector to demonstrate that exporters that are in the upper range of exporters' productivity distribution tend to use high technology and high-skilled workers than those in the lower range of the distribution. As AfT flows could be associated with higher employment levels (e.g., Gnangnon, 2018b) as well as greater employment diversification (e.g., Gnangnon, 2019a), we expect higher AfT flows to be associated with higher employment premium. This could, in turn, result in lower wage inequality between high-skilled and low-skilled (or unskilled) workers, depending on whether AfT interventions induce higher employment of low-skilled (or unskilled) workers than high-skilled workers in the manufacturing sector.

As AfT flows promote manufacturing exports in recipient-countries (e.g., Ghimire et al., 2013; Gnangnon, 2018c; Hühne et al., 2014a), they could widen the wage inequality. However, in fact, the effect of AfT flows on wage inequality in the manufacturing sector in recipient-countries depends on the degree of the manufacturing of export products. Indeed, Hühne et al. (2014a) used the Standard International Trade Classification (SITC) categories of exported products and reported a positive effect of AfT flows on different categories of SITC manufacturing

10) For firms, including manufacturing, see studies such as Aw and Hwang (1995) (for Taiwan), Bernard and Wagner (1997) (for Germany), Blalock and Gertler (2004) (for Indonesia), Isgut (2001) (Colombia), Turco and Maggioni (2013) (for Turkey) and, Bigsten et al. (2004), Rankin et al. (2006), Van Biesebroeck (2005) for Africa. 
export products. Gnangnon (2018c) used a panel dataset of 121 countries across 2002-2015 to show empirically that, on average, AfT flows have a positive effect on exports of low-skilled and technology-intensive manufacturers as well as high-skilled and technology-intensive manufacturers (compared with the total primary export products). However, no significant effect of AfT flows is observed on recipient-countries' exports of medium-skilled and technology-intensive manufactures. By contrast, LDCs benefit from AfT flows on exports of low-skilled and technology-intensive manufactures, but suffer on exports of medium-skilled and technology-intensive manufacture, and exports of high-skilled and technology-intensive manufactures. Therefore, AfT flows induce a relatively higher demand for low-skilled workers (and eventually a relatively higher wages of these workers) if these capital flows are associated with a rise in exports of low-skilled and technology-intensive products compared with other manufacturing products. Thus, AfT interventions reduce the wage gap between low-skilled and high-skilled workers in countries exporting low-skilled and technology-intensive manufactures. ${ }^{11)}$ This argument is relevant when AfT flows serve to rebuild a shrinking manufacturing sector. This is because in such as case, the level of unemployment rises and the level of employment declines (e.g., Autor et al., 2015; Charles et al., 2019), and these reduce the relative wages of workers at the lower end of the income distribution (e.g., Gould, 2018). The same effect might be expected for medium-skilled workers. However, AfT interventions could be associated with higher wage inequality between low-skilled (eventually medium-skilled) workers and high-skilled workers in case of higher exports of high-skilled and technology-intensive manufactures because its expansion would increase the demand for high-skilled workers rather than lower-skilled workers, thus widen the wage inequality between such workers.

Similarly, as AfT flows can be associated with greater export product diversification in recipient-countries (e.g., Gnangnon, 2019b, 2019c; Kim, 2019), these inflows would help increase the relative wages of low-skilled workers compared with that of skilled workers if they were associated with export product diversification toward light manufacturing products, that is, manufacturing products requiring low-skill, and are technology-intensive. In contrast, if AfT interventions were associated with greater export product diversification toward high-skilled and technology-intensive manufactures, they could drive the demand for high-skilled workers (consequently induce a relatively higher wage for those workers) and lead to a higher wage inequality in the manufacturing sector. This is consistent with the strand of literature that shows that product quality and destination of country characteristics affect the wages and type of workers employed by firms. For example, Verhoogen (2008) demonstrated through a Mexican study that the production of higher-quality goods requires higher-quality workers within each occupational category and those workers must receive higher wages. The study

11) This argument is plausible for the case of developing countries, given the bulk of low-skilled workers in these countries. 
explained that as higher incentives to export in a developing country is associated with differential quality upgrading, more productive plants would initially increase exports, produce a higher share of higher-quality goods, and raise wages compared with initially less-productive plants in the same industry. This process would lead to wage dispersion within the industry because firms that were initially more productive were likely to pay higher wages. Bernard et al. (2009) used data on the US manufacturing sector and showed that exporters of multiple products to multiple destinations employ more (skilled) workers and pay higher wages than those reliant on a single product or single destination. The study by Brambilla et al. (2012) on Argentina, supported by the work by Brambilla and Porto (2016) over 82 countries, found that export destinations tend to be "skill biased," whereby exporting (higher-quality products) to high-income countries has involved a relatively higher demand for skilled workers, and thus a relatively higher wage to those workers, compared with exporting to middle-income countries or selling in the domestic market. This implies that exporting higher-quality goods is associated with a higher wage inequality between high-skilled and low-skilled workers. Similarly, in an empirical study in South Africa, Rankin and Schöer (2013) revealed that domestic producers or firms that export to the regional (i.e., the South African Development Community -SADC) market and whose real per capita incomes are lower than those of the international market pay lower wages than firms that export to the international market. Moreover, this difference in wages is explained by the existence of a premium paid by various exporters for various levels of skills. Matthee et al. (2016) provided empirical support to the findings by Rankin and Schöer (2013). However, using data of sub-Saharan African manufacturing firms, Milner and Tandrayen (2007) found slightly different results. They reported that workers' wages are associated with firms' export status, and skill premium is associated with firms' exporting. In contrast with the findings of Matthee et al. (2016) and Rankin and Schöer (2013), Milner and Tandrayen (2007) observed that firms exporting to the African markets paid higher wages, while a negative wage premium is associated with exporting outside the African market. The authors explained these findings through the existence of a disciplining effect on the wages paid by exporting firms only if the latter have exported to more competitive markets.

\section{Effect of AfT flows on wage inequality through inward FDI}

Existing studies (e.g., Donaubauer et al., 2016; Lee \& Ries, 2016; Ly-My \& Lee, 2019) show a positive effect of AfT flows and FDI inflows. Lee and Ries (2016) showed that total AfT flows, particularly AfT for trade-related infrastructure and AfT for building a productive capacity, are positively associated with greenfield investment. Ly-My and Lee (2019) reported a positive FDI inflow effect of AfT flows and that AfT interventions help diversify greenfield FDI projects. Donaubauer et al. (2016) found empirical evidence that aid for economic infrastructure 
(infrastructure in transportation, communication, energy, and finance) enhances recipient-countries' endowments and, consequently, positively influences FDI flows to developing countries. However, Selaya and Sunesen (2012) emphasized that aid allocated to public infrastructure generates higher FDI inflows, while aid invested in physical capital transfers (i.e., directed toward productive sectors such as agriculture, manufacturing and banking) displaces FDI inflows. Dong and Fan (2017) showed that, among others, China's aid in the form of social and economic infrastructure increase FDI inflows from China to African countries, while aid allocated to the development of the productive sector displaces that from China to African countries.

Alternatively, FDI inflows can affect wage inequality between skilled and unskilled labor in the manufacturing sector through various ways, ${ }^{12}$ ) including innovation (introduction of new technologies/technology transfer in the host country), higher productivity, and employment. Figini and Görg (2011) used a sample comprising developed and developing countries and found that across the entire sample, there exists a nonlinear effect of FDI inward stock on wage inequality in the manufacturing sector. This nonlinear effect is robust for developing countries but not for developed countries. With respect to developing countries, wage inequality in the manufacturing sector increases with FDI inward stock, but diminishes with further FDI stock. Chen et al. (2011) used data on enterprises in the Chinese manufacturing sector and reported that higher FDI increased the inter-enterprise wage inequality. Suanes (2016) empirically observed over 13 Latin American economies that FDI in the manufacturing sector has a positive effect on income inequality. As wage represents a significant share of personal income for majority of people, the latter finding can be extended to wage inequality. Using data on Chinese industrial enterprises, Chen et al. (2017) reported that through their effect on labor transfer and technology spillovers, FDI inflows in China have contributed to reducing the wage gap between foreign and domestic firms.

Accordingly, it is assumed that as AfT interventions could be associated with higher FDI inflows in the recipient-countries, these interventions could result in higher wage inequality in the manufacturing sector through relatively higher demand for highly skilled workers. However, as the positive wage inequality effect of FDI decreases as FDI stock rises in developing countries (Figini \& Görg, 2011) or as FDI helps reduce the wage gap between foreign and domestic firms in the host country (Chen et al., 2017), AfT flows would be associated with lower wage inequality in the manufacturing sector as the size of FDI would further increase. Overall, the extent to which the effect of AfT flows on wage inequality in the manufacturing sector in recipient-countries depends on the size of FDI to these countries is an empirical matter.

12) See, for example, Figini and Görg (2011) and Peluffo (2015) for a literature review of the effect of FDI inflows on income inequality, and particularly wage inequality. 


\section{Empirical Model}

This study empirically examines the effect of AfT flows on wage inequality in the manufacturing sector of recipient-countries following the study by Figini and Görg (2011) and Martorano and Sanfilippo (2015). We consider a model specification that includes the variable of key interest (i.e., the AfT flows) and three control variables that could affect the influence of AfT flows on wage inequality in the manufacturing sector in recipient-countries. These controls include education level (EDU), which acts as a proxy for the level of human capital accumulated, inflation rate (INFL), and real per capita income (GDPC). Appendix 1 describes these three variables. Other key determinants of wage inequality in the manufacturing sector, such as trade liberalization (or trade openness), inward FDI flows (or stock), or technological development, are excluded in the baseline model because they represent the channels through which AfT interventions can affect wage inequality in the manufacturing sector. In the empirical analysis, the study examines whether these factors genuinely represent channels through which AfT flows affect the wage inequality variable. Following Figini and Görg (2011) and Martorano and Sanfilippo (2015), the education variable is included in the model to control for the supply side of the labor market, that is, the relative endowment of skilled labor. We expect that a higher education level increases the relative supply of skilled labor and reduces wage inequality (e.g., Figini \& Görg, 2011; Lankisch et al., 2019). However, a rise in the education level also reflects inequality in workers' education. Here, a higher education level could be associated with higher wage inequality, as high-skilled workers are better rewarded than lower-skilled workers are (e.g., Broecke et al., 2017). Several studies confirm the positive association between inflation and income inequality because inflation erodes the values of real wages, disproportionately influence income inequality, and increase income inequality (e.g., Albanesi, 2007; Bulír, 2001; Coibion et al., 2017; Lundberg \& Squire, 2003). However, there is no consensus on the effect of inflation on income inequality. For example, Chu et al. (2019) demonstrated the existence of an inverted-U-shape relationship between inflation and income inequality. However, Zheng (2020) showed that inflation that reduces economic growth mitigates income inequality by dampening the contribution of asset income relative to wage income. In this context, given that wages contribute significantly to the personal income of the majority in developing countries, the study concludes that the effect of inflation on wage inequality in the manufacturing sector might be positive or negative and remains an empirical issue. Finally, the introduction of the real capita income variable in model (1) captures countries' development level and ensures that the effect of AfT flows on wage inequality in the manufacturing does not capture that of the real per capita income (see a similar argument by Figini \& Görg, 2011; see also Sbardella et al., 2017).

We postulate the following model: 


$$
W I N E Q_{i t}=\alpha_{0}+\alpha_{1} W_{N N E Q_{i t-1}}+\alpha_{2} A f T_{i t}+\alpha_{3} G D P C_{i t}+\alpha_{4} E D U_{i t}+\alpha_{5} I N F L_{i t}+\mu_{i}+\vartheta_{t}+\omega_{i t}
$$

where the subscripts $i$ and $t$ are, respectively, a country's index and time. The panel dataset contains 65 countries over the period 1996-2016. The panel dataset is built based on data availability. In particular, we have used nonoverlapping subperiods of 3-year average data to mitigate the effects of business cycles on variables contained in model (1). These subperiods are 1996-1998, 1999-2001, 2002-2004, 2005-2007, 2008-2010, 2011-2013, and 2014-2016. The coefficients to be estimated are $\alpha_{0}$ to $\alpha_{5}$. $\mu_{i}$ represents countries' specific effects, and $\vartheta_{t}$ are the time dummies that reflect global shocks affecting the manufacturing sector wages (hence, the wage inequality) in all countries together. $\omega_{i t}$ is an idiosyncratic error term. Introduction of the one-period lag of the dependent variable as a regressor in model (1) captures the inertia in the index of wage inequality in the manufacturing sector. This inertia arises from the lagged effects of the explanatory variables on wage inequality and in the model, this inertia allows for differentiating between the short term and long-term effect of explanatory variables on wage inequality in the manufacturing sector.

The dependent variable "WINEQ" represents the wage inequality in the manufacturing sector. It is the Theil index of wage inequality computed for each country and every year from 1996 to 2016. Following Figini and Görg (2011), we used a measure of general wage inequality between sectors and between workers, rather than a measure of the gap between wages of skilled and unskilled workers, such as that used by Martorano and Sanfilippo (2015). The Theil index of wage inequality is computed using the country-year data from United Nations Industrial Development Organization on the average wages per employee across 3-digit International Standard Industrial Classification manufacturing industries, which is weighted by the number of employees in each sector.

The variable "AfT" represents the real gross disbursements of AfT flows. In this study, total AfT flows (denoted "AfTTOT") is the main measure of AfT flows, but two components of total AfT flows (the sum of these two components amounts to total AfT flows) are also used. These include the real gross disbursements of AfT flows allocated to the industry sector (denoted "AfTIND") and the real gross disbursements of AfT allocated to all sectors other than the industry sector (denoted "AfTNONIND"), both components being expressed in constant prices 2016 (US Dollar). In principle, data on the gross disbursements of AfT flows contained in the OECD database are obtained from 2002 onward. However, for this study, the data have been extended13) from 1996 to 2016 to obtain a large sample of observations and potentially medium-term effects. This study follows the approach proposed by Clemens et al. (2012), Thiele et al. (2006) and Selaya and Sunesen (2012) (see Appendix 2 for the description of this

13) A similar approach for the expansion of AfT data has been used by Hühne et al. (2014b). 
approach), and the recent study by Gnangnon (2020b).

To avoid drawbacks of units of measurement when interpreting and comparing results arising from estimations of model (1) and its variants, all five variables contained in model (1) are standardized, as well as all other variables (e.g., trade policy, trade openness, and FDI), which are the channel variables through which the total AfT flows can affect wage inequality in the manufacturing sector. By standardizing all variables, time dummies in the regressions are excluded as their standardized values are equal to zero. The standardization procedure involves calculating the ratio of the difference between the concerned variable and its mean (average) to the standard deviation of this variable for each variable. The coefficients resulting from regressions based on standardized variables (standardized coefficients) are compared and ranked in terms of their contribution to explaining the dynamics of wage inequality in the manufacturing sector. Appendices $3 \mathrm{a}$ and $3 \mathrm{~b}$ provide the standard descriptive statistics, respectively, on unstandardized (i.e., normal) and standardized variables. Appendix 4 lists the 65 countries used in the analysis.

\section{Data Analysis}

Before interpreting the empirical results, it is important to understand the correlation between (unstandardized) AfT flows (including total AfT flows and those allocated to the industry sector and other sectors) and wage inequality in the manufacturing sector. Figure 1 presents the developments of these indicators over the panel dataset under analysis using their average values. Figure 2 shows the correlation between total AfT flows and wage inequality using both unstandardized and standardized values (see, respectively, the left-hand side and the right-hand side graphs in Figure 2). Figure 1 shows an erratic evolution of wage inequality, including contrasting AfT flow variables. The three AfT flow variables move in the same direction. In particular, they have significantly declined from 1996-1998 to 2002-2004, and subsequently increased over the rest of the period; although during the past sub-period, AfT flows to the industry sector declined. These positive movements of AfT flows after 2004 reflect the positive AfT Initiative effect. Interestingly, AfT flows dedicated to the nonindustry sectors represent an important share of the total AfT flows. Total AfT flows, AfT flows for the nonindustry sectors, and AfT flows allocated to the industry sector amounted, respectively, to US\$ 411.8 million, US\$ 398 million, and US\$ 27.2 million in 1996-1998, against US\$ 129.3 million, US\$ 121 million, and US\$ 8.34 million in 2002-2004. Both total AfT flows and AfT for nonindustry sectors reached, respectively, US\$ 347.2 million and US\$ 326 million in 2011-2013, while on this sub-period, AfT flows for the industry sector represented only US\$ 21 million. Finally, in 2014-2016, both total AfT flows and AfT for nonindustry sectors reached, respectively, US\$ 399.1 million and US\$ 387 million, while AfT for the industry sector 
amounted to US\$ 11.8 million (against US\$ 21 million in 2011-2013). Figure 2 shows an unclear direction of the correlation pattern between total AfT flows and wage inequality in the manufacturing sector in the two graphs. Nevertheless, Figure 2 shows the absence of outliers in the graph plotted using the standardized variables (right-hand side graph), whereas outliers are present in the left-hand side graph based on unstandardized variables. In other words, the use of standardized variables has helped eliminate outlier problems.

Figure 1. Cross-plot between AfT flows and WINEQ

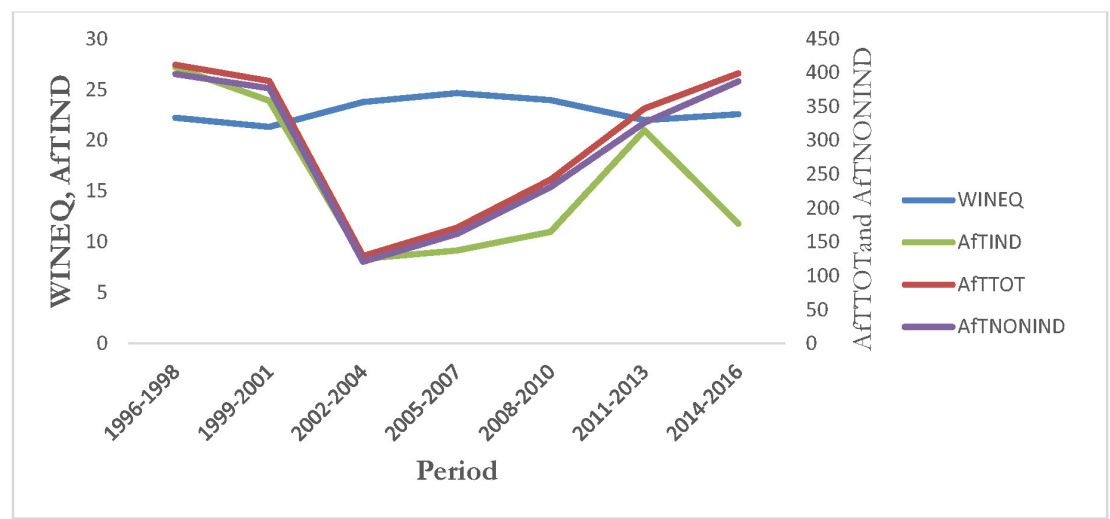

(Source) Author

Note. The variables "AfTTOT", "AfTIND" and "AfTNONIND" represent respectively total AfT flows, AfT flows allocated to the industry sector, and AfT flows for the non-industry sector. They are expressed in millions of US\$, Constant 2016 Prices.

Figure 2. Cross-plot between total AfT flows and wage inequality in the manufacturing sector
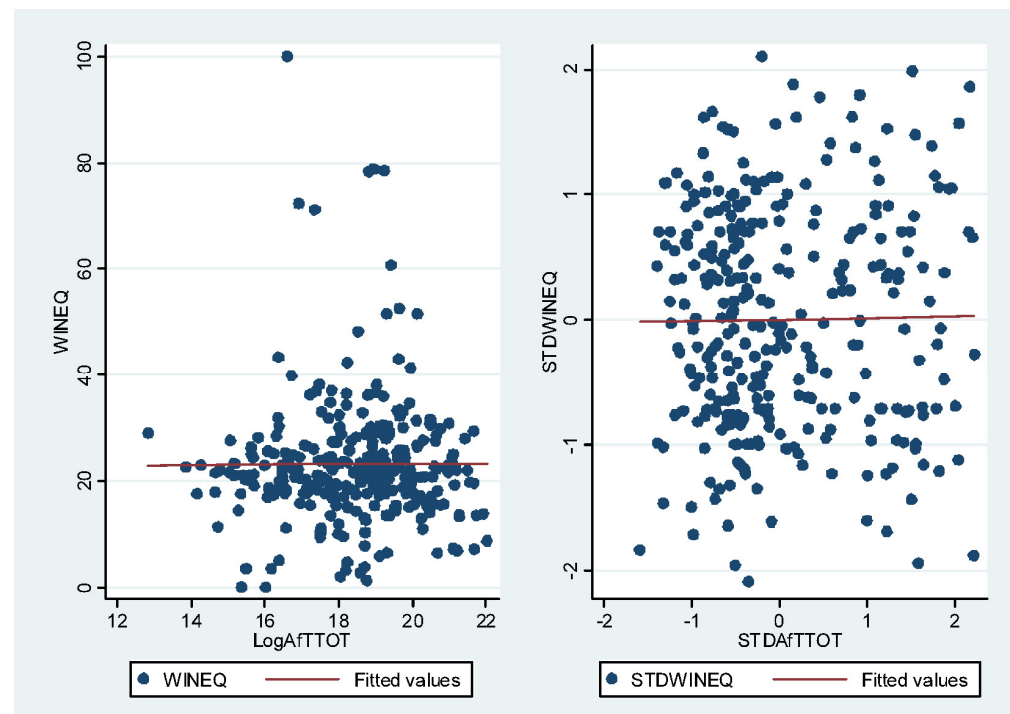

(Source) Author 


\section{Estimation Technique}

Model (1) or its different variants are estimated using the two-step system Generalized Methods of Moments (GMM) estimator, which is suitable for dynamic panels with a small time dimension and large cross section (see Arellano \& Bover, 1995; Blundell \& Bond, 1998). This estimator (also used by Figini \& Görg, 2011) was chosen because of its advantages in addressing several endogeneity concerns, compared to other estimators such as the first-difference GMM approach. First, by considering the inertia in wage inequality in the manufacturing sector in model (1), a correlation is introduced between the one-period lag of the dependent variable and countries (unobservable) specific characteristics. This correlation leads to biased and inconsistent estimates (known as Nickell bias, see Nickell, 1981) because the time dimension of the panel dataset in this study is small and the cross-section dimension relatively large. Second, regressors in model (1) capturing AfT flows, the education level, and the real per capita income are potentially endogenous because of the reverse causality and simultaneity bias. Given the limited number of countries in the sample, and to avoid the proliferation of instruments used in the regressions, the inflation variable is considered as exogenous, but results do not change when it is considered endogenous. The exogeneity of this variable rests on the absence of a reverse causality from the dependent to the inflation variable, simply because of the relatively small size of the manufacturing sector in many developing countries (the public sector is the main job provider in many developing countries, including least-developed ones). Therefore, it is unlikely that wage inequality, due to the rise of the relative wage of skilled workers than that of unskilled workers, would fuel inflation in these countries. Third, the system GMM estimator helps overcome the endogeneity problem arising from the omitted variable bias. The two-step system GMM approach involves the estimation of a system of equations (i.e., equations in level and in differences) where lagged values are used as instruments for the first-differenced regressors, and first differences as instruments for the equation levels. In principle, estimates arising from regressions based on the two-step system GMM are fully consistent if the null hypotheses of the Arellano-Bond test of first-order serial correlation in the error term (denoted $\mathrm{AR}(1)$ ) and no second-order autocorrelation in the error term (denoted $\mathrm{AR}(2))$ are not rejected; and if the Sargan test of over-identifying restrictions (OID), which determines the validity of the instruments used in the estimations, generates $p$-values higher than 0.10 (at the $10 \%$ level). Additionally, the Arellano-Bond test of no third-order serial correlation in the error term (denoted $\mathrm{AR}(3)$ ) is presented as failure to reject the null hypothesis might reflect a problem of omitted variable(s). Finally, these tests are powerful if the number of instruments is lower than the number of countries (Bowsher, 2002; Roodman, 2009; Ziliak, 1997). To meet this rule of thumb, a maximum of three lags of dependent variable and three lags of endogenous variables were used as instruments in the two-step system GMM-based regressions. 
Hence, the following specifications of model (1) are estimated over the full sample of 65 countries ${ }^{14)}$ during 1996-2016. Table 1 presents the outcomes of the estimations of model (1), including using "AfTTOT" as the measure of the variable "AfT" (see column [1] of Table 1) or its components highlighted earlier (see column [2]). Column [3] of Table 1 contains the outcomes of the estimation of a variant of model (1) that includes the interaction between the total AfT flows variable and the real per capita income variable. These outcomes help examine the extent to which the effect of total AfT flows on wage inequality in the manufacturing sector varies across the 65 countries in the entire sample, based on their real per capita income.

Table 1. Impact of AfT Flows on Wage Inequality in the Manufacturing Sector

Estimator: Two-Step System GMM

\begin{tabular}{|c|c|c|c|}
\hline Variables & $\begin{array}{c}\text { WINEQ } \\
\text { (1) }\end{array}$ & $\begin{array}{c}\text { WINEQ } \\
\text { (2) }\end{array}$ & $\begin{array}{c}\text { WINEQ } \\
\text { (3) }\end{array}$ \\
\hline \multirow[t]{2}{*}{ WINEQ $_{\mathrm{t}-1}$} & $0.380 * * *$ & $0.388 * * *$ & $0.392 * * *$ \\
\hline & $(0.0333)$ & $(0.00976)$ & $(0.0161)$ \\
\hline \multirow[t]{2}{*}{ AfTTOT } & $-0.114^{* *}$ & & $-0.125 * * *$ \\
\hline & $(0.0488)$ & & $(0.0247)$ \\
\hline \multirow[t]{2}{*}{ AfTIND } & & $-0.0907 * * *$ & \\
\hline & & $(0.0159)$ & \\
\hline \multirow[t]{2}{*}{ AfTNONIND } & & $-0.0863 * * *$ & \\
\hline & & $(0.0238)$ & \\
\hline \multirow[t]{2}{*}{ AfTTOT*GDPC } & & & $-0.0316^{* *}$ \\
\hline & & & $(0.0136)$ \\
\hline \multirow[t]{2}{*}{ GDPC } & $-0.240 * * *$ & $-0.223 * * *$ & $-0.248 * * *$ \\
\hline & $(0.0456)$ & $(0.0280)$ & $(0.0290)$ \\
\hline \multirow[t]{2}{*}{ EDU } & $0.189 * * *$ & $0.129 * * *$ & $0.206^{* * *}$ \\
\hline & $(0.0475)$ & $(0.0145)$ & $(0.0210)$ \\
\hline \multirow[t]{2}{*}{ INFL } & $-0.233 * * *$ & $-0.137 * * *$ & $-0.212 * * *$ \\
\hline & $(0.0335)$ & $(0.0114)$ & $(0.0205)$ \\
\hline \multirow[t]{2}{*}{ Constant } & 0.00216 & 0.00196 & 0.0206 \\
\hline & $(0.0226)$ & $(0.0132)$ & $(0.0135)$ \\
\hline Observations - Countries & $234-65$ & $234-65$ & $234-65$ \\
\hline Number of Instruments & 48 & 59 & 62 \\
\hline AR1 (P-Value) & 0.0011 & 0.0011 & 0.0012 \\
\hline AR2 (P-Value) & 0.7876 & 0.9073 & 0.7957 \\
\hline AR3 (P-Value) & 0.3065 & 0.1855 & 0.3294 \\
\hline OID (P-Value) & 0.4246 & 0.5273 & 0.5842 \\
\hline
\end{tabular}

Note. ${ }^{*} p$-value $<0.1 ; * *$-value $<0.05 ; * * * p$-value $<0.01$. Robust Standard Errors are in parenthesis.

14) Exclusion from the sample of countries such as Republic of Korea (that was previously a recipient of AfT) does not change the empirical outcomes of the analysis quantitatively and qualitatively. 
Table 2 helps examine how total AfT flows affect wage inequality in the manufacturing sector through trade liberalization (trade openness) channel. These results are obtained by estimating three different variants of model (1) that incorporate a variable capturing trade liberalization/trade openness and its interaction with the total AfT flows variable. Three

Table 2. Impact of AfT Flows on Wage Inequality in the Manufacturing Sector for Varying Levels of Trade Liberalization/Trade Openness

Estimator: Two-Step System GMM

\begin{tabular}{|c|c|c|c|}
\hline Variables & $\begin{array}{l}\text { WINEQ } \\
\text { (1) }\end{array}$ & $\begin{array}{c}\text { WINEQ } \\
\text { (2) }\end{array}$ & $\begin{array}{c}\text { WINEQ } \\
\text { (3) }\end{array}$ \\
\hline WINEQ $_{\mathrm{t}-1}$ & $\begin{array}{l}0.364 * * * \\
(0.0204)\end{array}$ & $\begin{array}{l}0.387 * * * \\
(0.00981)\end{array}$ & $\begin{array}{c}0.377 * * * \\
(0.0133)\end{array}$ \\
\hline AfTTOT & $\begin{array}{c}-0.119 * * * \\
(0.0241)\end{array}$ & $\begin{array}{l}0.00315 \\
(0.0241)\end{array}$ & $\begin{array}{c}-0.129 * * * \\
(0.0326)\end{array}$ \\
\hline AfTTOT*DTP & $\begin{array}{c}-0.189 * * * \\
(0.0248)\end{array}$ & & \\
\hline AfTTOT*OPEN & & $\begin{array}{c}-0.193^{* * *} \\
(0.0276)\end{array}$ & \\
\hline AfTTOT*OPENSW & & & $\begin{array}{c}-0.285 * * * \\
(0.0238)\end{array}$ \\
\hline DTP & $\begin{array}{c}-0.112 * * * \\
(0.0239)\end{array}$ & & \\
\hline OPEN & & $\begin{array}{c}-0.0350^{* *} \\
(0.0136)\end{array}$ & \\
\hline OPENSW & & & $\begin{array}{c}0.121^{* * *} \\
(0.0206)\end{array}$ \\
\hline GDPC & $\begin{array}{c}-0.258^{* * *} \\
(0.0300)\end{array}$ & $\begin{array}{c}-0.261^{* * *} \\
(0.0376)\end{array}$ & $\begin{array}{c}-0.393 * * * \\
(0.0281)\end{array}$ \\
\hline EDU & $\begin{array}{c}0.260 * * * \\
(0.0310)\end{array}$ & $\begin{array}{l}0.103 * * * \\
(0.0145)\end{array}$ & $\begin{array}{c}0.250 * * * \\
(0.0374)\end{array}$ \\
\hline INFL & $\begin{array}{c}-0.254^{* * *} \\
(0.0200)\end{array}$ & $\begin{array}{c}-0.175^{* * *} \\
(0.0217)\end{array}$ & $\begin{array}{c}-0.222 * * * \\
(0.0160)\end{array}$ \\
\hline Constant & $\begin{array}{c}0.0412 * * * \\
(0.0123)\end{array}$ & $\begin{array}{c}0.0289 \\
(0.0188)\end{array}$ & $\begin{array}{c}0.0413^{* *} \\
(0.0207)\end{array}$ \\
\hline Observations - Countries & $229-63$ & $231-64$ & $231-64$ \\
\hline Number of Instruments & 60 & 60 & 60 \\
\hline AR1 (P-Value) & 0.0005 & 0.0023 & 0.0019 \\
\hline AR2 (P-Value) & 0.5771 & 0.5601 & 0.7165 \\
\hline AR3 (P-Value) & 0.5533 & 0.6117 & 0.6199 \\
\hline OID (P-Value) & 0.6012 & 0.5290 & 0.4881 \\
\hline
\end{tabular}

Note. ${ }^{*} p$-value $<0.1 ;{ }^{*} p$-value $<0.05 ;{ }^{* * *} p$-value $<0.01$. Robust Standard Errors are in parenthesis. 
alternative trade policy/trade openness variables have been used in the analysis. The first variable is the trade policy index (de Jure measure of trade policy (DTP)), that is, the score of freedom to trade internationally, developed by the Heritage Foundation (see Miller et al., 2019). "DTP" is a composite index of the absence of tariff and nontariff barriers that affect imports and exports of goods and services. Higher values of "DTP" indicate lower trade barriers, that is, greater trade policy liberalization. The second measure (denoted "OPEN") is the standard indicator of trade openness (i.e., de facto trade openness) measured by the sum of exports and imports, expressed as a percentage of GDP. The third measure is also a de facto indicator of trade openness (denoted "OPENSW"), and was proposed by Squalli and Wilson (2011). "OPENSW" is computed by weighing the standard measure of trade openness ("OPEN") by the proportion of a country's trade level relative to the average world trade (Squalli \& Wilson, 2011). Compared with the standard trade openness measure, this indicator genuinely reflects countries' level of integration into the international trade market.

Table 3 displays the results of the estimations of other specifications of model (1) that allow assessment of the extent to which the effect of total AfT flows on wage inequality in the manufacturing sector depends on the size of inward FDI to the AfT recipient-countries. These specifications of model (1) include a variable measuring the size of FDI and its interaction with the total AfT flows variable. Specifically, two main measures of the size of FDI (i.e., in terms of flows and stock) expressed in real values and as a percentage of GDP (of the AfT recipient-countries) are used: these include the total inward FDI stock and the net FDI inflows. Table 4 displays the outcomes of the estimations that help examine how the effect of total AfT flows on wage inequality in the manufacturing sector passes through countries' manufacturing exports. Therefore, various specifications of model (1) are estimated that include a variable measuring countries' manufacturing export performance and its interaction with the total AfT flows variable. Manufacturing export performance is measured by either the share of total manufacturing exports products in total export products (denoted "MANEXP") or the components of the latter. These components include the total export products share (\%) of labor-intensive and resource-intensive product exports (denoted "LABEXP"), low-skill and technology-intensive product exports (denoted "LOWEXP"), medium-skill and technology-intensive product exports (denoted "MEDEXP"), and high-skill and technology-intensive product exports (denoted "HIGHEXP"). This analysis is also complemented by assessing the extent to which the effect of total AfT flows on wage inequality in the manufacturing sector depends on recipient-countries' level of export product diversification. To do so, a variant of model (1) is estimated that includes both a variable measuring the level of export product concentration (denoted "ECI"), whose inverse reflects export product diversification, and the interaction of this variable with the total AfT flows variable. The outcomes of this estimation are also provided in Table 4. 
662 Journal of Economic Integration Vol. 35, No. 4

Table 3. Impact of AfT Flows on Wage Inequality in the Manufacturing Sector for Varying Sizes of Inward FDI

Estimator: Two-Step System GMM

\begin{tabular}{|c|c|c|c|c|}
\hline Variables & $\begin{array}{l}\text { WINEQ } \\
\text { (1) }\end{array}$ & $\begin{array}{c}\text { WINEQ } \\
\text { (2) }\end{array}$ & $\begin{array}{l}\text { WINEQ } \\
\text { (3) }\end{array}$ & $\begin{array}{c}\text { WINEQ } \\
\text { (4) }\end{array}$ \\
\hline \multirow[t]{2}{*}{ WINEQ $_{\mathrm{t}-1}$} & $0.406^{* * *}$ & $0.421 * * *$ & $0.394 * * *$ & $0.399 * * *$ \\
\hline & $(0.0220)$ & $(0.0191)$ & $(0.0124)$ & $(0.0102)$ \\
\hline \multirow[t]{2}{*}{ AfTTOT } & -0.00599 & 0.0274 & $-0.0748 * *$ & $-0.135^{* * *}$ \\
\hline & $(0.0242)$ & $(0.0429)$ & $(0.0365)$ & $(0.0327)$ \\
\hline \multirow[t]{2}{*}{ AfTTOT*FDISTOCKCST } & $-0.135^{* * *}$ & & & \\
\hline & $(0.0284)$ & & & \\
\hline \multirow[t]{2}{*}{ AfTTOT*FDISTOCKGDP } & & $-0.0760 * * *$ & & \\
\hline & & $(0.0182)$ & & \\
\hline \multirow[t]{2}{*}{ AfTTOT*FDIFLOWSCST } & & & $-0.0841 * *$ & \\
\hline & & & $(0.0358)$ & \\
\hline \multirow[t]{2}{*}{ AfTTOT*FDIFLOWSGDP } & & & & $-0.124 * *$ \\
\hline & & & & $(0.0584)$ \\
\hline \multirow[t]{2}{*}{ FDISTOCKCST } & $-0.0901 *$ & & & \\
\hline & $(0.0490)$ & & & \\
\hline \multirow[t]{2}{*}{ FDISTOCKGDP } & & $2.92 \mathrm{e}-05$ & & \\
\hline & & $(0.0309)$ & & \\
\hline \multirow[t]{2}{*}{ FDIFLOWSCST } & & & $0.117 * * *$ & \\
\hline & & & $(0.0264)$ & \\
\hline \multirow[t]{2}{*}{ FDIFLOWSGDP } & & & & 0.00237 \\
\hline & & & & $(0.0446)$ \\
\hline \multirow[t]{2}{*}{ GDPC } & $-0.131 * * *$ & $-0.206^{* * *}$ & $-0.358 * * *$ & $-0.239 * * *$ \\
\hline & $(0.0321)$ & $(0.0192)$ & $(0.0240)$ & $(0.0310)$ \\
\hline \multirow[t]{2}{*}{ EDU } & $0.157 * * *$ & 0.0190 & $0.248 * * *$ & $0.182 * * *$ \\
\hline & $(0.0201)$ & $(0.0512)$ & $(0.0330)$ & $(0.0292)$ \\
\hline \multirow[t]{2}{*}{ INFL } & $-0.245 * * *$ & $-0.196^{* * *}$ & $-0.209 * * *$ & $-0.205 * * *$ \\
\hline & $(0.0236)$ & $(0.0183)$ & $(0.0284)$ & $(0.0213)$ \\
\hline \multirow[t]{2}{*}{ Constant } & 0.0106 & 0.0149 & 0.00239 & 0.00955 \\
\hline & $(0.0199)$ & $(0.0193)$ & $(0.0134)$ & $(0.0135)$ \\
\hline Observations - Countries & $234-65$ & $234-65$ & $234-65$ & $234-65$ \\
\hline Number of Instruments & 57 & 60 & 57 & 57 \\
\hline AR1 (P-Value) & 0.0010 & 0.0007 & 0.0007 & 0.0007 \\
\hline AR2 (P-Value) & 0.8394 & 0.9678 & 0.7793 & 0.7215 \\
\hline AR3 (P-Value) & 0.2980 & 0.2277 & 0.3265 & 0.4627 \\
\hline OID (P-Value) & 0.3008 & 0.4732 & 0.4787 & 0.3930 \\
\hline
\end{tabular}

Note. ${ }^{*} p$-value $<0.1 ;{ }^{*} p$-value $<0.05 ;{ }^{* *} p$-value $<0.01$. Robust Standard Errors are in parenthesis. 
Table 4. Impact of AfT Flows on Wage Inequality in the Manufacturing Sector for Varying Levels of Manufactured Export Performance/Export Product Diversification

Estimator: Two-Step System GMM

\begin{tabular}{|c|c|c|c|c|c|c|}
\hline Variables & $\begin{array}{c}\text { WINEQ } \\
(1)\end{array}$ & $\begin{array}{c}\text { WINEQ } \\
(2)\end{array}$ & $\begin{array}{c}\text { WINEQ } \\
\text { (3) }\end{array}$ & $\begin{array}{c}\text { WINEQ } \\
\text { (4) }\end{array}$ & $\begin{array}{c}\text { WINEQ } \\
(5)\end{array}$ & $\begin{array}{c}\text { WINEQ } \\
(6)\end{array}$ \\
\hline WINEQ $_{\mathrm{t}-1}$ & $\begin{array}{c}0.395 * * * \\
(0.0153)\end{array}$ & $\begin{array}{c}0.426 * * * \\
(0.0230)\end{array}$ & $\begin{array}{c}0.367 * * * \\
(0.0355)\end{array}$ & $\begin{array}{c}0.412 * * * \\
(0.0171)\end{array}$ & $\begin{array}{c}0.394 * * * \\
(0.0146)\end{array}$ & $\begin{array}{c}0.374 * * * \\
(0.0181)\end{array}$ \\
\hline AfTTOT & $\begin{array}{c}-0.107 * * * \\
(0.0167)\end{array}$ & $\begin{array}{l}-0.0397 \\
(0.0439)\end{array}$ & $\begin{array}{c}-0.136^{* * *} \\
(0.0288)\end{array}$ & $\begin{array}{l}-0.00490 \\
(0.0258)\end{array}$ & $\begin{array}{c}-0.0820 * * * \\
(0.0268)\end{array}$ & $\begin{array}{c}-0.0860 * * * \\
(0.0293)\end{array}$ \\
\hline AfTTOT*MANEXP & $\begin{array}{l}-0.00127 \\
(0.00962)\end{array}$ & & & & & \\
\hline AfTTOT*LABEXP & & $\begin{array}{c}-0.159 * * * \\
(0.0280)\end{array}$ & & & & \\
\hline AfTTOT*LOWEXP & & & $\begin{array}{l}-0.143 * * \\
(0.0652)\end{array}$ & & & \\
\hline AfTTOT*MEDEXP & & & & $\begin{array}{r}-0.00745 \\
(0.0353)\end{array}$ & & \\
\hline AfTTOT*HIGHEXP & & & & & $\begin{array}{c}-0.0965 * * \\
(0.0387)\end{array}$ & \\
\hline AfTTOT*ECI & & & & & & $\begin{array}{c}-0.124 * * * \\
(0.0339)\end{array}$ \\
\hline MANEXP & $\begin{array}{c}0.131 * * * \\
(0.0282)\end{array}$ & & & & & \\
\hline LABEXP & & $\begin{array}{c}0.0174 \\
(0.0312)\end{array}$ & & & & \\
\hline LOWEXP & & & $\begin{array}{l}-0.0522 \\
(0.0380)\end{array}$ & & & \\
\hline MEDEXP & & & & $\begin{array}{c}-0.228^{* * *} \\
(0.0332)\end{array}$ & & \\
\hline HIGHEXP & & & & & $\begin{array}{c}0.151 * * * \\
(0.0418)\end{array}$ & \\
\hline ECI & & & & & & $\begin{array}{c}0.251 * * * \\
(0.0257)\end{array}$ \\
\hline GDPC & $\begin{array}{c}-0.159 * * * \\
(0.0119)\end{array}$ & $\begin{array}{c}-0.270 * * * \\
(0.0199)\end{array}$ & $\begin{array}{c}-0.207 * * * \\
(0.0186)\end{array}$ & $\begin{array}{c}-0.207 * * * \\
(0.0377)\end{array}$ & $\begin{array}{c}-0.225^{* * *} \\
(0.0264)\end{array}$ & $\begin{array}{c}-0.305 * * * \\
(0.0353)\end{array}$ \\
\hline EDU & $\begin{array}{c}0.141 * * * \\
(0.0291)\end{array}$ & $\begin{array}{c}0.138 * * * \\
(0.0456)\end{array}$ & $\begin{array}{c}0.129 * * * \\
(0.0419)\end{array}$ & $\begin{array}{c}0.127 * * * \\
(0.0343)\end{array}$ & $\begin{array}{c}0.0750 \\
(0.0508)\end{array}$ & $\begin{array}{c}0.140 * * * \\
(0.0171)\end{array}$ \\
\hline INFL & $\begin{array}{c}-0.194 * * * \\
(0.0167)\end{array}$ & $\begin{array}{c}-0.152 * * * \\
(0.0144)\end{array}$ & $\begin{array}{c}-0.174 * * * \\
(0.0230)\end{array}$ & $\begin{array}{c}-0.209^{* * *} \\
(0.0230)\end{array}$ & $\begin{array}{c}-0.193 * * * \\
(0.0173)\end{array}$ & $\begin{array}{c}-0.131 * * * \\
(0.0223)\end{array}$ \\
\hline Constant & $\begin{array}{l}-0.0113 \\
(0.0132)\end{array}$ & $\begin{array}{l}-0.0160 \\
(0.0208)\end{array}$ & $\begin{array}{c}-0.0343 * \\
(0.0185)\end{array}$ & $\begin{array}{c}0.0180 \\
(0.0190)\end{array}$ & $\begin{array}{c}0.0224 \\
(0.0184)\end{array}$ & $\begin{array}{l}-0.0144 \\
(0.0144)\end{array}$ \\
\hline Observations - Countries & $234-65$ & $234-65$ & $234-65$ & $234-65$ & $234-65$ & $234-65$ \\
\hline Number of Instruments & 60 & 57 & 57 & 57 & 57 & 57 \\
\hline AR1 (P-Value) & 0.0008 & 0.0011 & 0.0007 & 0.0011 & 0.0004 & 0.0020 \\
\hline AR2 (P-Value) & 0.9329 & 0.6967 & 0.6912 & 0.9358 & 0.8291 & 0.7805 \\
\hline AR3 (P-Value) & 0.3266 & 0.2573 & 0.4502 & 0.2971 & 0.2415 & 0.0866 \\
\hline OID (P-Value) & 0.6108 & 0.4631 & 0.4207 & 0.6616 & 0.3839 & 0.5321 \\
\hline
\end{tabular}

Note. ${ }^{*} p$-value $<0.1 ;{ }^{* *} p$-value $<0.05 ;{ }^{* *} p$-value $<0.01$. Robust Standard Errors are in parenthesis. 
This study also examined the extent to which the effect of AfT flows on wage inequality in the manufacturing sector depends on the imports of various manufacturing goods. Such estimations help understand whether an SBTC effect of AfT flows exist through imports of products that incorporate technology and knowledge and that can translate to technological progress in the importing countries that are AfT recipient-countries. This analysis is made by estimating other specifications of model (1) in which an indicator capturing the import of manufacturing products is introduced along with its interaction with the total AfT flows variable. This indicator can be the total import products share (\%) of total manufacturing imports (denoted "MANIMP"), medium-skill/and high-skill and technology-intensive product imports (denoted "MEDHIGHIMP"), and machinery and transport equipment imports (denoted "MACHIMP"). Table 5 presents the results of these various estimations are provided in.

Table 5. Impact of AfT on Wage Inequality in the Manufacturing Sector for Varying Shares of Manufactured Import (In Total Import Products)

Estimator: Two-Step System GMM

\begin{tabular}{|c|c|c|c|}
\hline Variables & $\begin{array}{c}\text { WINEQ } \\
\text { (1) }\end{array}$ & $\begin{array}{c}\text { WINEQ } \\
\text { (2) }\end{array}$ & $\begin{array}{c}\text { WINEQ } \\
\text { (3) }\end{array}$ \\
\hline WINEQ $_{\mathrm{t}-1}$ & $0.382 * * * \quad(0.0266)$ & $0.367 * * * \quad(0.0234)$ & $0.348^{* * *} \quad(0.0220)$ \\
\hline AfTTOT & $-0.0806 * *(0.0321)$ & $-0.0293 \quad(0.0187)$ & $-0.0396(0.0289)$ \\
\hline AfTTOT*MANIMP & $-0.234 * * * \quad(0.0325)$ & & \\
\hline AfTTOT*MEDHIGHIMP & & $-0.216 * * * \quad(0.0398)$ & \\
\hline AfTTOT*MACHIMP & & & $-0.161^{* * *}(0.0545)$ \\
\hline MANIMP & $-0.126^{* * *} \quad(0.0266)$ & & \\
\hline MEDHIGHIMP & & $-0.0330 \quad(0.0210)$ & \\
\hline MACHIMP & & & $0.104 * * \quad(0.0477)$ \\
\hline GDPC & $-0.306 * * * \quad(0.0246)$ & $-0.315 * * * \quad(0.0263)$ & $-0.297 * * * \quad(0.0266)$ \\
\hline EDU & $0.204 * * * \quad(0.0369)$ & $0.199 * * * \quad(0.0441)$ & $0.227 * * * \quad(0.0292)$ \\
\hline INFL & $-0.224 * * * \quad(0.0177)$ & $-0.210 * * * \quad(0.0123)$ & $-0.198 * * * \quad(0.0209)$ \\
\hline Constant & $-0.00649 \quad(0.0193)$ & $0.0258 \quad(0.0182)$ & $0.0292 *(0.0164)$ \\
\hline Observations - Countries & $234-65$ & $234-65$ & $234-65$ \\
\hline Number of Instruments & 57 & 57 & 57 \\
\hline AR1 (P-Value) & 0.0006 & 0.0006 & 0.0010 \\
\hline AR2 (P-Value) & 0.8995 & 0.7607 & 0.7318 \\
\hline AR3 (P-Value) & 0.2268 & 0.3089 & 0.3753 \\
\hline OID (P-Value) & 0.3801 & 0.2762 & 0.3742 \\
\hline
\end{tabular}

Note. ${ }^{*} p$-value $<0.1 ;{ }^{*} p$-value $<0.05 ;{ }^{* *} p$-value $<0.01$. Robust Standard Errors are in parenthesis.

Finally, whether the effect of total AfT flows on wage inequality in the manufacturing sector depends on the potential degree of multilateral trade liberalization that an AfT recipient-country 
can enjoy when acceding to the international trade market is analyzed in depth. A specification of model (1) that includes an indicator of multilateral trade liberalization and its interaction with the total AfT flows variable is analyzed. Table 6 presents the results of the estimation of this specification of model (1). Following Ratnaike (2012) and Gnangnon (2017a,b; 2018d; 2019d,e), multilateral trade liberalization is defined as "all trade-related decisions-including those adopted at the multilateral level under the ambit of the WTO-that ultimately contribute to the reduction of tariffs and non-tariffs barriers to trade by all countries, or at least by the overwhelming majority of countries." For the empirical analysis, multilateral trade liberalization is defined as the average "domestic" trade policy of the rest of the world. Thus, for a given country, it is the average of the score of freedom to trade internationally (the indicator "DTP" defined earlier) with the rest of the world. Multilateral trade liberalization lowers tariffs and nontariff barriers on products exported by countries including developing ones. In particular, it contributes to reducing tariff peaks and escalations that prevent developing countries from adding significant value to their export products, and diversifying their export product basket. Gnangnon (2019d) reported the positive export product diversification effect of multilateral trade liberalization. Beverelli et al. (2015) demonstrated that the WTO's (multilateral) Trade Facilitation Agreement can help countries diversify their export products basket both at the extensive margins (i.e., by increasing the number of products exported by destination) and in terms of the number of

Table 6. Effect of AfT Flows on Wage Inequality in the Manufacturing Sector for Varying Degrees of Multilateral Trade Liberalization

Estimator: Two-Step System GMM

\begin{tabular}{|c|c|}
\hline Variables & $\begin{array}{c}\text { WINEQ } \\
\text { (1) }\end{array}$ \\
\hline WINEQ $_{\mathrm{t}-1}$ & $0.385 * * * \quad(0.0147)$ \\
\hline AfTTOT & $-0.113 * * * \quad(0.0254)$ \\
\hline AfTTOT*MTP & $-0.0623 * * \quad(0.0257)$ \\
\hline MTP & $-0.280 * * * \quad(0.0394)$ \\
\hline GDPC & $-0.0945^{*} \quad(0.0547)$ \\
\hline EDU & $0.331 * * * \quad(0.0237)$ \\
\hline INFL & $-0.182 * * * \quad(0.0185)$ \\
\hline Constant & $0.0516 * * * \quad(0.0104)$ \\
\hline Observations - Countries & $234-65$ \\
\hline Number of Instruments & 60 \\
\hline AR1 (P-Value) & 0.0014 \\
\hline AR2 (P-Value) & 0.6720 \\
\hline AR3 (P-Value) & 0.3107 \\
\hline OID (P-Value) & 0.7683 \\
\hline
\end{tabular}

Note. ${ }^{*} p$-value $<0.1 ;{ }^{* *} p$-value $<0.05 ;{ }^{* * *} p$-value $<0.01$. Robust Standard Errors are in parenthesis. 
export destinations. Gnangnon (2017a) also showed that multilateral trade liberalization stimulates FDI inflows. Therefore, multilateral trade liberalization can affect wage inequality through export product diversification and inward FDI channels, as discussed earlier. As AfT flows also affect wage inequality in the manufacturing sector through these two channels, both AfT interventions and multilateral trade liberalization can reinforce or substitute each other in influencing wage inequality in the manufacturing sector. Hence, AfT flows can lead to lower wage inequality in the manufacturing sector in the context of greater multilateral trade liberalization, or widen wage inequality as countries enjoy greater multilateral trade liberalization, depending on the direction in which export product diversification and inward FDI influence wage inequality in the manufacturing sector. The issue is, therefore, purely empirical.

\section{Empirical outcomes}

First, the test outcomes help examine the validity of the two-step system GMM estimator for the empirical analysis (see the bottom of all columns of Tables 1-6) are fully satisfactory, as the null hypotheses of these tests nearly hold good15) and the $p$-values of the OID test are all higher than 0.10. Additionally, across the six tables, the coefficient of the one-period lag of the dependent variable is positive and always significant at the $1 \%$ level. This shows the existence of inertia in the wage inequality variable, and hence underlines the use of the dynamic specification in model (1). Moreover, the number of instruments is always lower than the number of countries used in the regressions. From now onwards, the expression "wage inequality" is sometimes used to refer to "wage inequality in the manufacturing sector."

Estimates in column [1] of Table 1 show that at the 5\% level, total AfT flows are negatively associated with wage inequality, thereby suggesting that higher total AfT flows contribute to reducing wage inequality in the manufacturing sector. As previously discussed, this can occur through various channels, including trade policy liberalization (or trade openness), manufacturing export performance, export product diversification, inward FDI, imports of manufactured products, and the extent of multilateral trade liberalization. This negative effect of total AfT flows on wage inequality is confirmed when results in column [2] are considered. In particular, both AfT flows for the industry sector and those allocated to the nonindustry sectors have a negative and significant effect (at the $1 \%$ level) on wage inequality. These suggest that AfT interventions contribute to the increase in the wages of unskilled (or low-skilled) workers (or

15) The exception here concerns the results of the AR(3) test displayed at the bottom of column [6] of Table. As the $p$-value associated with the $\operatorname{AR}(3)$ test is 0.0866 , we reject the null hypothesis related to this test at the $5 \%$ level. Thus, at the 5\% level, results in columns [6] of Table 4 are reliable. It is important to recall that the $\mathrm{AR}(3)$ test is not mandatory as it is not clearly recommended by the proponents of the two-step system GMM estimator. 
to the reduction of wages across different sub-sectors) in the manufacturing sector. Regarding the magnitude of these impacts, a 1 standard deviation in total AfT flows induces a fall in wage inequality by a 0.114 standard deviation (Appendix 3a contains the standard deviation of all variables used in the analysis). Similarly, a 1 standard deviation in AfT flows for the industry sector and that related to the nonindustry sectors are associated with a fall in wage inequality, respectively, by a 0.091 standard deviation and a 0.086 standard deviation. The extent of the effect of these two components of total AfT flows on wage inequality is similar. Results in column [3] show that the coefficient of "AfTTOT" and the interaction term related to the interaction variable (between total AfT flows and the real per capita income variables) are both negative and significant (at the $1 \%$ level for the former and $5 \%$ for the latter). These two outcomes indicate that total AfT flows always have a negative effect on wage inequality (regardless of the level of the real per capita income), and the magnitude of this negative effect increases as the real per capita income rises. In sum, the total AfT flows greatly reduce wage inequality in advanced developing countries than in relatively less advanced countries. In the three columns of Table 1, coefficients of control variables exhibit the same sign and statistically significance, although these coefficients are sometimes different. In particular, a higher education level widens the wage inequality, while an increase in the real per capita income and higher inflation rates reduce wage inequality. Among all variables in columns [1] and [2] of Table 1, the real per capita income explains the most the dynamics of wage inequality. The real per capita income variable is followed by the inflation rate, the education level, and finally the AfT flows variables. Thus, AfT flows variables least explain the dynamics of wage inequality in recipient-countries. However, as the effects of AfT flows variables on wage inequality passes through several factors that are hitherto not incorporated in the regressions, the rank in terms of the contribution of AfT interventions to explain the dynamics of wage inequality might change significantly once these factors are considered.

Column [1] of Table 2 reports that the coefficient of both "AfTTOT" and the interaction of the latter with "DTP" are both negative and significant at the $1 \%$ level. These suggest that irrespective of the degree of trade policy liberalization, the total AfT flows always reduce wage inequality as countries further liberalize their domestic trade policies. In column [2] of Table 2 , the coefficient of "AfTTOT" is not significant at the conventional levels, while the interaction term associated with the variable between "AfTTOT" and "OPEN" is negative and significant at the $1 \%$ level. These signify that higher total AfT flows consistently reduce wage inequality, and the magnitude of this negative effect increases as countries experience greater trade openness. Across columns [1] and [2] of Table 2, greater trade policy liberalization and trade openness are negatively and significantly associated with wage inequality. Estimates in column [3] show negative and significant coefficients (at the 1\% level) of "AfTTOT" and of the interaction between the latter and the variable "OPENSW." This confirms the findings in 
columns [1] and [2] that the magnitude of the reduction in the wage inequality effect of total AfT flows increase as countries enjoy greater trade openness, including a greater "genuine" participation in world trade. Overall, the results in Table 2 show that AfT interventions (total AfT flows) favor wages of unskilled workers (or reduce wages across different sub-sectors) in the manufacturing sector, in particular, as countries experience a higher level of trade policy liberalization or greater trade openness.

Across the four columns in Table 3,16) the interaction terms of the variable between total AfT flows and size of inward FDI are all negative, but significant at the $1 \%$ level when the AfT variable is interacted with the inward FDI stock, either in real terms or as percentage of GDP) (see columns [1] and [2]) and significant at the 5\% level when the AfT variable is interacted with the net FDI inflows variables, expressed either in real values or as a percentage of GDP (see columns [3] and [4]). Simultaneously, the variable "AfTTOT" exhibits coefficients in columns [1] and [2] that are not significant at the conventional levels, while in columns [3] and [4], the coefficients are significant at least at the 5\% level. Therefore, AfT interventions reduce wage inequality in countries that enjoy a higher inward FDI, with the magnitude of this negative effect increasing as the size of inward FDI rises. These results can be interpreted as AfT interventions help reduce the SBTC effect of inward FDI on wage inequality by favoring the employment of low-skilled workers within a subsector of the manufacturing sector or in many sub-sectors of the manufacturing sector, and hence reducing the wage gap between low-skilled and high-skilled workers.

Column [1] of Table 4 suggests that the effect of total AfT flows on wage inequality does not depend on the share of total manufacturing exports in total export products because the term associated with the interaction variable between "AfTTOT" and "MANTOTEXP" is not significant at the conventional levels, although the coefficient of "AFTTOT" is negative and significant at the $1 \%$ level. However, this outcome hides, as shown across columns [2] to [5] of Table 4, the fact that AfT interventions can exert a significant effect on wage inequality when considering different components of total manufacturing exports as a share of total export products). In particular, across columns [2] and [3], at least at the 5\% level, total AfT flows contribute to lowering wage inequality in countries with a higher share of labor-intensive and resource-intensive product exports (in total export products) or alternatively a higher share of low-skill and technology-intensive product exports (in total export products). These outcomes are consistent with our theoretical expectations that AfT flows lead to lower wage inequality if they are used to promote the export of labor-intensive (or low-skilled) manufacturing products. In addition, in column [5], at the 5\% level, total AfT flows reduce wage inequality as countries

16) It is noteworthy that we have followed Figini and Görg (2011) and introduced the squared terms of the inward FDI variable in the model specifications, but we have consistently not found a non-linear effect of FDI on the wage inequality variable. 
experience a rise in high-skill and technology-intensive product exports. This suggests that by providing workers with jobs and income opportunities, AfT interventions contribute to reducing the wage gap between low-skilled (or unskilled) workers and high-skilled workers, when countries enjoy an increase in high-skill manufactured exports, which were supposed to stimulate the demand for skilled labor and increase wage inequality. This result also shows that AfT flows help reduce the inter-"sub"sectorial wage gap within the manufacturing sector when countries experience an increase in high-skill manufactured exports. In contrast to these findings, results in column [4] suggest that at the conventional levels, medium-skill, and technology-intensive product exports do not impact the effect of total AfT flows on wage inequality.

Finally, results in column [6] of Table 4 suggest that the coefficient of both "AfTTOT" and the coefficient of the interaction between total AfT flows and the export product concentration index are negative and significant at the $1 \%$ level. Incidentally, the variable "ECI" shows a positive and significant coefficient at the $1 \%$ level. Overall, these outcomes suggest that AfT flows reduce wage inequality in countries that experience a high level of export product concentration. Moreover, the greater this level, the higher is the magnitude of the reducing effect of total AfT flows on wage inequality. One practical interpretation of this result can be that AfT interventions provide unskilled (or low-skilled) workers with the opportunities to either have access to an income-generating activity or improve their export revenue. Therefore, AfT flows help reduce the wage gap between high-skilled and low-skilled (or unskilled) labor in countries that experience a greater export product concentration (as in many developing countries, export products are usually concentrated on low-value added products, and is, therefore, associated with a high wage inequality between skilled and unskilled workers). Table 5 shows that across the three columns, the coefficients of the interaction variables ["AfTTOT*SHMANIMP"], ["AfTTOT*MEDHIGHIMP"], and ["AfTTOT*MACHIMP"] are all negative and significant at the $1 \%$ level. Concurrently, the "AfTTOT" variable holds a negative and significant coefficient (at the 1\% level) only in column [1], as in the two other columns, the coefficient of this variable is not significant at the conventional levels. Therefore, total AfT flows has a higher negative effect on wage inequality as countries experience a higher share of total imports of manufacturing products, a higher share of imports of manufacturing products intensive in both medium-skill and high-skill and technology, or a rise in the share of imports of machinery and transport equipment (all expressed as a percentage of total import products). Thus, AfT flows helps dampen the widening wage inequality effect that may be associated with the import of manufacturing products (and its possibly associated SBTC effect).

Table 6 indicates negative and significant coefficients (at the 1\% level) for both "AfTTOT" and the interaction variable ["AfTTOT*SMTP"]. Hence, higher amounts of total AfT flows negatively influence wage inequality in the context of greater multilateral trade liberalization. In particular, the magnitude of this reducing wage inequality effect of AfT flows increases 
as countries enjoy a greater extent of multilateral trade liberalization. However, the variable "MTP" holds a negative and significant coefficient (at the $1 \%$ level) thereby suggesting greater multilateral trade liberalization induces lower wage inequality (though this coefficient should be interpreted along with the interaction term of the interaction variable).

Results concerning the control variables in Tables 2-6 are similar to those in Table 1.

\section{Conclusion}

This study provided an empirical analysis of the effect of AfT interventions on wage inequality in the manufacturing sector of recipient-countries. The analysis used a sample of 65 countries during 1996-2016 and produced interesting results. AfT flows reduce wage inequality in the manufacturing sector of recipient-countries that have liberalized their trade regimes, enjoy greater trade openness, increase their manufacturing exports (labor-intensive manufacturing export products, low-skill-intensive manufacturing exports and high-skill-intensive manufacturing exports), and import manufacturing products (e.g., imports of machinery and transport equipment goods). AfT interventions also help in mitigating the negative effect of export product concentration (including on primary products) on wage inequality in the manufacturing sector. Finally, AfT flows reduce wage inequality in the manufacturing sector of countries that enjoy much multilateral trade liberalization.

Overall, this analysis reveals that AfT flows affect not only recipient-countries' trade performance but also the wage inequality in the manufacturing sector of these countries through various channels.

\section{References}

Acemoglu, D. (2003). Cross-country inequality trends. The Economic Journal, 113(485), F121-F149. Albanesi, S. (2007). Inflation and inequality. Journal of Monetary Economics, 54(4), 1088-1114.

Alvarez, R., \& López, R. A. (2005). Exporting and performance: evidence from Chilean plants. Canadian Journal of Economics, 38(4), 1384-1400.

Amiti, M., \& Davis, D. R. (2012). Trade, firms, and wages: Theory and evidence. The Review of Economic Studies, 79(1), 1-36.

Anwar, S., \& Sun, S. (2012). Trade liberalisation, market competition and wage inequality in China's manufacturing sector. Economic Modelling, 29(4), 1268-1277.

Arellano, M., \& Bover, O. (1995). Another look at the instrumental variable estimation of error-components models. Journal of Econometrics, 68(1), 29-51. 
Attanasio, K. P., Goldberg, P., \& Pavcnik, N. (2004). Trade reforms and wage inequality in Colombia. Journal of development Economics, 74, 331-366.

Autor, D. H., Dorn, D., \& Hanson, G. H. (2015). Untangling trade and technology: evidence from local labor markets. Economic Journal, 125(584), 621-46.

Aw, B. Y., \& Hwang, A. R. M. (1995). Productivity and the export market: A firm-level analysis. Journal of Development Economics, 47(2), 313-32.

Bas, M. (2012). Technology adoption, export status, and skill upgrading: Theory and evidence. Review of International Economics, 20(2), 315-31.

Baumgarten, D. (2013). Exporters and the rise in wage inequality: Evidence from German linked employer-employee data. Journal of International Economics, 90(1), 201-17.

Berman, E., \& Machin, S. (2000). Skill-Biased technology transfer around the world. Oxford Review of Economic Policy, 16(1), 12-22.

Berman, E., Somanathan, R., \& Tan, H. (2005). Is skill-biased technological change here yet? Evidence from Indian manufacturing in the 1990s. Annals d'Economie et de Statistique, ENSAE, 79(80), 299-321.

Bernard, A. B., \& Jensen, J. B. (1995). Exporters, jobs, and wages in U.S. manufacturing: 1976-1987. Brookings Papers on Economic Activity. Microeconomics, 67-119.

Bernard, A., \& Jensen, J. (1997). Exporters, skill upgrading, and the wage gap. Journal of International Economics, 42(1-2), 3-31.

Bernard, A., \& Jensen, J. (1999). Exceptional exporter performance: cause, effect, or both? Journal of International Economics, 47(1), 1-25.

Bernard, A. B., \& Wagner, J. (1997). Exports and success in German manufacturing. Weltwirtschaftliches Archiv, 133(1), 134-57.

Bernard, A. B., Jensen, J. B., \& Schott, P. K. (2009). Importers, Exporters and Multinationals: A Portrait of Firms in the US that Trade Goods. In Producer Dynamics (Eds.), New Evidence from Micro Data (pp. 513-552). Cambridge, MA: National Bureau of Economic Research.

Berrittella, M. (2017). Can stability of foreign aid agreement reduce global income inequality? Economic Analysis and Policy, 54, 105-111.

Beverelli, C., Neumueller, S., \& The, R. (2015). Export Diversification Effects of the WTO Trade Facilitation Agreement, World Development, 76, 293-310.

Bigsten, A., Collier, P., Dercon, S., Fafchamps, M., Gauthier, B., Willem Gunning, J., Oduro, A., Oostendorp, R., Pattillo, C., Söderbom, M., \& Teal, F. (2004). Do African manufacturing firms learn from exporting? Journal of Development Studies, 40(3), 115-41.

Bjørnskov, C. (2010). Do elites benefit from democracy and foreign aid in developing countries? Journal of Development Economics, 92(2), 115-124.

Blalock, G., \& Gertler, P. J. (2004). Learning from exporting revisited in a less developed setting. Journal of Development Economics, 75(2), 397-416.

Blundell, R., \& Bond, S. (1998). Initial conditions and moment restrictions in dynamic panel data models. Journal of Econometrics, 87, 115-143.

Bourguignon, F., Levin, V., \& Rosenblatt, D. (2009). International Redistribution of Income. World Development, 37(1), 1-10. 
Bowsher, C. G. (2002). On testing overidentifying restrictions in dynamic panel data models. Economics Letters, 77(2), 211-220.

Brambilla, I., \& Porto, G. G. (2016). High-income Export Destinations, Quality and Wages. Journal of International Economics, 98, 21-35.

Brambilla, I., Carneiro, R. D., Lederman, D., \& Porto, G. (2012). Skills, Exports, and the Wages of Seven Million Latin American Workers. The World Bank Economic Review, 26(1), 34-60.

Brambilla, I., Lederman, D., \& Porto, G. (2012). Exports, export destinations, and skills. The American Economic Review, 102(7), 3406-38.

Brambilla, I., N. D. Chauvin, \& G. Porto (2015). Wage and Employment Gains from Exports: Evidence from Developing Countries. CEPII Working Paper No 2015-28. Available at: http://www.cepii.fr/PDF_ PUB/wp/2015/wp2015-28.pdf (accessed on 19 January 2017).

Broecke, S., Quintini, G., \& Vandeweyer, M. (2017). Explaining international differences in wage inequality: Skills matter. Economics of Education Review, 60, 112-124.

Buliŕ, A. (2001). Income inequality: Does inflation matter? IMF Staff Papers, 48(1), 139-159.

Bustos, P. (2011). The impact of trade liberalization on skill upgrading evidence from Argentina. The American Economic Review, 101(1), 304-340.

Bustos, P. (2011). Trade liberalization, exports, and technology upgrading: Evidence on the impact of MERCOSUR on Argentinian firms. The American Economic Review, 101(1), 304-340.

Cadot, O., Fernandes, A., Gourdon, J., Mattoo, A., \& de Melo, J. (2014). Evaluating Aid for Trade: A Survey of Recent Studies. The World Economy, 37(4), 516-529.

Calderon, C., Chong, A., \& Gradstein, M. (2009). Can foreign aid reduce income inequality and poverty? Public Choice, 140, 59-84.

Card, D., \& DiNardo, J. E. (2002). Skill-biased technological change and rising wage inequality: Some problems and puzzles. Journal of Labor Economics, 20(4), 733-783.

Chao, C-C., Laffargue J-P., \& Sgro, P. M. (2010). Foreign Aid, Wage Inequality, and Welfare for a Small Open Economy with Tourism. Review of International Economics, 18(3), 454-464.

Charles, K. K., Hurst, E., \& Notowidigdo, M. J. (2019). Housing booms, manufacturing decline and labor market outcomes. Economic Journal, 129(617), 209-248.

Chaudhuri, S., \& Yabuuchi, S. (2007). Economic liberalization and wage inequality in the presence of labor market imperfection. International Review of Economics and Finance, 16(4), 592-603.

Chen, C., H. Zhao, \& Y. Zhou (2017). Foreign Direct Investment and Wage Inequality: Evidence from the People's Republic of China. ADBI Working Paper 734. Tokyo: Asian Development Bank Institute.

Chen, Z., Ge, Y., \& Lai, H. (2010). Foreign direct investment and wage inequality: Evidence from China. World Development, 39(8), 1322-1332.

Chen, Z., Ge, Y., \& Lai, H. (2011). Foreign direct investment and wage inequality: evidence from China. World Development, 39(8), 1322-1332.

Chu, A. C., Cozzi, G., Fan, H., Furukawa, Y., \& Liao, C. H. (2019). Innovation and inequality in a monetary schumpeterian model with heterogeneous households and firms. Review of Economic Dynamics, 34, 141-164.

Clemens, M., Radelet, S., Bhavnani, R., \& Bazzi, S. (2012). Counting chickens when they hatch: The 
short-term effect of aid on growth. Economic Journal, 122(561), 590-617.

Coibion, O., Gorodnichenko, Y., Kueng, L., Silvia, J. (2017). Innocent bystanders? Monetary policy and inequality. Journal of Monetary Economics, 88, 70-89.

Currie, J., \& Harrison, A. (1997). Sharing the costs: the impact of trade reform on capital and labor in Morocco. Journal of Labor Economics, 15, 44-69.

Davis, D. R. (1996). Trade liberalisation and income distribution. NBER Working Papers \#5693 Cambridge, M.A., National Bureau of Economic Research.

Donaubauer, J., Meyer, B., \& Nunnenkamp, P. (2016). Aid, infrastructure and FDI: Assessing the transmission channel with a new index of infrastructure. World Development, 78, 230-245.

Dong, Y., \& Fan, G. (2017). The effects of China's aid and trade on its ODI in African countries. Emerging Markets Review, 33, 1-18.

Ebenstein, A., Harrison, A., McMillan, M., \& Phillips, S. (2014). Estimating the impact of trade and offshoring on American workers using the current population surveys. Review of Economics and Statistics, 96(4), 581-95.

Egger, H., \& Kreickemeier, U. (2009). Firm heterogeneity and the labor market effects of trade liberalization. International Economic Review 50(1), 187-216.

Feenstra, R. C., \& Hanson, G. H. (1996). Foreign investment, outsourcing and relative wages. In R. C. Feenstra, G. M. Grossman, \& D. A. Irwin (Eds.), The political economy of trade policy: Papers in honor of Jagdish Bhagwati (pp. 89-127). Cambrige, MA: MIT Press.

Feenstra, R. C., \& Hanson, G. H. (1997). Foreign direct investment and relative wages: evidence from Mexico's maquiladoras. Journal of International Economics, 42(3-4), 371-393.

Feenstra, R. C., \& Hanson, G. H. (1999). The impact of outsourcing and high-technology capital on wages: Estimates for the U.S., 1979-1990. Quarterly Journal of Economics, 114(3), 907-940.

Feenstra, R. C., \& Hanson, G. H. (2001). Global production sharing and rising inequality: A survey of trade and wages. In E. K. Choi \& J. Harrigan (Eds.), Handbook of international trade (pp. 146-185). Oxford: Blackwell.

Feliciano, Z. M. (2001). Workers and trade liberalization: the impact of trade reforms in Mexico on wages and employment. Industrial and Labor Relations Review, 55(1), 95-115.

Figini, P., \& Görg, H. (2011). Does foreign direct investment affect wage inequality? An empirical investigation. The World Economy, 34(9), 1455-1475.

Galiani, S., \& Sanguinetti, P. (2003). The impact of trade liberalization on wage inequality: evidence from Argentina. Journal of Development Economics, 72, 2-17.

Ghazali, M. (2011). Trade liberalization, rent sharing and wage inequality in Tunisia, 1998-2002. Economie internationale, 1(125), 5-39.

Ghimire, S., Mukherjee, D., \& Alvi, E. (2013). Sectoral aid for trade and sectoral exports: a seemingly unrelated regression analysis. Economic Bulletin, 33(4), 2744-2755.

Gnangnon, S. K. (2017a). Multilateral trade liberalization and foreign direct investment inflows. Economic Affairs, 37(1), 66-84.

Gnangnon, S. K. (2017b). Multilateral trade liberalization and government revenue. Journal of Economic Integration, 32(3), 586-614. 
Gnangnon, S. K. (2018a). Aid for Trade and trade policy in recipient-countries. The International Trade Journal, 32(5), 439-464.

Gnangnon, S. K. (2018b). Aid for Trade and sectoral employment diversification in recipient-countries. Economic Change and Restructuring, 53(2), 1-31.

Gnangnon, S. K. (2018c). Aid for trade and recipient-countries' export structure: Does trade policy liberalization matter? Arthaniti: Journal of Economic Theory and Practice, 18(1), 56-85.

Gnangnon, S. K. (2018d). Impact of trade imbalances on domestic trade policy: Does multilateral trade policy matter? Review of Development Economics, 22(4), e266-e289.

Gnangnon, S. K. (2019a). Aid for trade and employment in developing countries: An empirical evidence. Labor, Review of Labor Economics and Industrial Relations, 33(1), 77-100.

Gnangnon, S. K. (2019b). Aid for trade and export diversification in recipient-countries. The World Economy, 42(2), 396-418.

Gnangnon, S. K. (2019c). Does the impact of aid for trade on export product diversification depend on structural economic policies in recipient-countries? Economic Issues, 24(1), 59-87.

Gnangnon, S. K. (2019d). Multilateral trade liberalisation helps promote export product diversification: Trade tensions damage the prospects of the poorest economies. Economic Affairs, 39(3), 363-380.

Gnangnon, S. K. (2019e). Fiscal space for trade: How could the international trade community help? Journal of International Commerce, Economics and Policy, 10(1), 1950001.

Gnangnon, S. K. (2020a). Aid for trade and services export diversification in recipient-countries. ECONSTOR Preprints 210467, ZBW - Leibniz Information Centre for Economics.

Gnangnon, S. K. (2020b). Comparative Advantage Following (CAF) development strategy, Aid for Trade flows and structural change in production. Journal of Economic Structures 2020, 9, 1.

Goh, C. C., \& Javorcik, B. S. (2005). Trade protection and industry wage structure in Poland. Policy. Research Working Paper Series, 3552, The World Bank, 15-17.

Goldberg, P. K., \& Nina, P. (2004). Trade, inequality, and poverty: what do we know? Evidence from recent trade liberalization episodes in developing countries. In Collins, S.M., Graham, C. (Eds.), Brookings Trade Forum2004 (pp. 223-269). Washington, D.C.: Brookings Institution Press.

Goldberg, P. K., \& Nina, P. (2005). Trade, wages, and the political economy of trade protection: evidence from the Colombian trade reforms. Journal of International Economics 66(1), 75-105.

Goldberg, P. K., \& Nina, P. (2007). Distributional effects of globalization in developing countries. Journal of Economic Literature 45(1), 39-82.

Gould, E. D. (2018). Explaining the unexplained: Residual wage inequality, manufacturing decline and low-skilled immigration. The Economic Journal, Early View - Online Version at https://doi.org/10.1111 /ecoj.12611

Gourdon, J. (2011). Wage inequality in developing countries: South-South trade matters. International Review of Economics, 58(4), 359-383.

Hahn, C. H., \& Choi, Y. S. (2017). Trade liberalisation and the wage skill premium in korean manufacturing plants: do plants' R\&D and investment matter? The World Economy, 40(6), 1214-1232.

Hanson, G., \& A. Harrison (1999). Trade and wage inequality in Mexico. Industrial and Labor Relations Review, 52(2), 271-288. 
Harrison, A., McLaren, J., \& McMillan, M. (2011). Recent perspectives on trade and inequality. Annual Review of Economics, 3, 261-289.

Harrison, R. (2008). Skill-biased technology adoption: Firm-level evidence from Brazil and India (No.08/03). The Institute for Fiscal Studies Working Paper.

Helpman, E., \& Krugman, P. (I989). Trade policy and market structure. Cambridge, MA: MIT Press.

Helpman, E., Itskhoki, O., \& Redding, S. (2010). Inequality and unemployment in a global economy. Econometrica, 78(4), 1239-1283.

Herzer, D. (2011). The long-run relationship between outward FDI and total factor productivity: Evidence for developing countries. Journal of Development Studies, 47, 767-785.

Herzer, D., \& Nunnenkamp, P. (2012). The effect of foreign aid on income inequality: Evidence from panel cointegration. Structural Change and Economic Dynamics, 23(3), 245-255.

Hühne, P., Meyer, B., \& Nunnenkamp, P. (2014a). Aid for trade: Assessing the effects on recipient exports of manufactures and primary commodities to donors and non-donors. Kiel Working Papers, No 1953. Kiel Institute for the World Economy (IfW), Kiel, Germany.

Hühne, P., Meyer, B., \& Nunnenkamp, P. (2014b). Who benefits from aid for trade? Comparing the effects on recipient versus donor exports. Journal of Development Studies, 50(9), 1275-1288.

Isgut, A. (2001). What's different about exporters? Evidence from Colombian manufacturing. Journal of Development Studies, 37(5), 57-82.

ITC/WTO. (2014). SME competitiveness and Aid for Trade - Connecting developing country SMEs to global value chains. International Trade Centre (ITC)- World Trade Organization (WTO) Technical Paper No. DMD-14-264-E, 40 pages. Geneva: ITC/WTO.

Kaufmann, D., Kraay, A., \& Mastruzzi, M. (2010). The worldwide governance indicators methodology and analytical issues. World Bank Policy Research $\mathrm{N}^{\circ} 5430$ (WPS5430), Washington, D.C.

Kijima, Y. (2006). Why did wage inequality increase? Evidence from urban India 1983-99. Journal of Development Economics, 81(1), 97-117.

Kim, Y. R. (2019). Does aid for trade diversify the export structure of recipient countries? The World Economy, 42(9), 2684-2722.

Klein, M. W., Moser, C., \& Urban, D. M. (2013). Exporting, skills and wage inequality. Labor Economics, 25, 76-85.

Kong, D., Kong, G., Pang, L., \& Zhang, J. (2018). Who gets the wage premium from export: Top managers or employees? International Review of Economics \& Finance, 58, 356-370.

Lankisch, C., Prettner, K., \& Prskawetz, A. (2019). How can robots affect wage inequality? Economic Modelling, 81, 161-169.

Layton, T., \& Nielson, D. (2008). Aiding inequality: The effect of foreign aid on income inequality. Mimeo, Brigham Young University.

Lee, H. H., \& Ries, J. (2016). Aid for Trade and Greenfield Investment. World Development, 84(C), 206-218.

Lee, J. W., \& Wie, D. (2015). Technological change, skill demand, and wage inequality: Evidence from Indonesia. World Development, 67, 238-250.

Lundberg, M., \& Squire, L. (2003). The simultaneous evolution of growth and inequality. Economic 
Journal, 113(487), 326-344.

Ly-My, D., \& Lee, H. H. (2019). Effects of aid for trade on extensive and intensive margins of greenfield FDI. The World Economy, 42(7), 2120-2143.

Martorano, B., \& Sanfilippo, M. (2015). Structural change and wage inequality in the manufacturing sector: Long run evidence from East Asia. Oxford Development Studies, 43(2), 212-231.

Matthee, M., Rankin, N., \& Bezuidenhout, C. (2017). Labor demand and the distribution of wages in South African manufacturing exporters. UNU-WIDER Working Paper 2017/11. Helsinki: UNU-WIDER.

Matthee, M., Rankin, N., Naughtin, T., \& Bezuidenhout, C. (2016). The South African Manufacturing Exporter Story. UNU-WIDER Working Paper 2016/038. Helsinki: UNU-WIDER.

Melitz, M. J. (2003). The impact of trade on intra-industry reallocations and aggregate industry productivity. Econometrica, 71(6), 1695-1725.

Miller, T., Kim, A. B., Roberts, J. M., \& Tyrrell, P. (2019). 2019 Index of Economic Freedom, Institute for Economic Freedom, The Heritage Foundation, Washington, DC. See online: https://www.heritage.o rg/index/pdf/2019/book/index_2019.pdf

Milner, C., \& Tandrayen, V. (2007). The impact of exporting and export destination on manufacturing wages: Evidence for Sub-Saharan Africa. Review of Development Economics, 11(1), 13-30.

Mishra, P., \& Kumar, U. (2005). Trade liberalization and wage inequality: Evidence from India, IMF staff working paper WP/05/20, International Monetary Fund, Washington, D.C.

Nagel, K., Herzer, D., \& Nunnenkamp, P. (2015). How does FDI affect health? International Economic Journal, 29(4), 655-679.

Nickell, S. (1981). Biases in dynamic models with fixed effects. Econometrica, 49(6), 1417-1426.

Odedokun, M. (2003). Analysis of deviations and delays in aid disbursements. Journal of Economic Development, 137(28), 137-169.

OECD. (2010). Trading out of poverty - How aid for trade can help? OECD Journal on Development, $10(2), 7-41$.

OECD/WTO. (2015). Aid for Trade at a Glance 2015: Reducing Trade Costs for Inclusive, Sustainable Growth. In Chapter 7: How Aid for Trade helps reduce the burden of trade costs on SMEs. Contributed by the International Trade Centre. WTO, Geneva/OECD Publishing, Paris.

OECD/WTO. (2017). Aid for Trade at a Glance 2017: Promoting Trade, Inclusiveness and Connectivity for Sustainable Development. In Chapter 11: Financing Connectivity: Aid for Trade Priorities, Policies, and Programmes. Contributed by the Organisation for Economic Cooperation and Development. WTO, Geneva/OECD Publishing, Paris.

OECD/WTO. (2019). Aid for Trade at a Glance 2019: Economic Diversification and Empowerment. In Chapter 9: Empowering youth for sustainable trade. Contributed by the International Trade Centre. WTO, Geneva/OECD Publishing, Paris.

Peluffo, A. (2015). Foreign direct investment, productivity, demand for skilled labor and wage inequality: An analysis of Uruguay. The World Economy, 38(6), 962-983.

Pham, T. H. H. (2015). Income inequality and foreign aid. Working Paper $n^{\circ} 2015 / 13$, LEMNA, Institute of Economics and Management, University of Nantes, France.

Rankin, N., \& Schöer, V. (2013). Export destination, product quality and wages in a middle-income 
country. The case of South Africa. Review of Development Economics, 17(1), 64-73.

Rankin, N. A., Söderbom, M., \& Teal, F. (2006). Exporting from manufacturing firms in sub-Saharan Africa. Journal of African Economies, 15(4), 671-87.

Ratnaike, Y. C. (2012). Is there an empirical link between trade liberalisation and export performance? Economics Letters, 117, 375-378.

Revenga, A. (1997). Employment and Wage Effects of Trade Liberalization: The Case of Mexican Manufacturing. Journal of Labor Economics, 15(3), 20-43.

Roodman, D. M. (2009). A note on the theme of too many instruments. Oxford Bulletin of Economic and Statistics, 71(1), 135-158.

Rose, N. L. (1987). Labor market sharing and regulation: evidence from the tracking industry. The Journal of political Economy, 95(6), 1146-1178.

Sbardella, A., Pugliese, E., \& Pietronero, L. (2017). Economic development and wage inequality: A complex system analysis. PLoS ONE, 12(9), e0182774.

Schank, T., Schnabel, C., \& Wagner, J. (2007). Do exporters really pay higher wages? First evidence from German linked employer-employee data. Journal of International Economics, 72(1), 52-74.

Selaya, P., \& Sunasen, E. R. (2012). Does foreign aid increase foreign direct investment?. World Development, 40(11), 2155-76.

Sen, K. (2008). Trade policy and wage inequality: evidence from Indian manufacturing. Indian Growth and Development Review, 1(2), 147-171.

Serti, F., Tomasi, C., \& Zanfei A. (2010). Who trades with whom? Exploring the links between firms' international activities, skills, and wages. Review of International Economics, 18(5), 951-71.

Squalli, J., \& Wilson, K. (2011). A new measure of trade openness. The World Economy, 34(10), 1745-1770.

Suanes, M. (2016). Foreign direct investment and income inequality in Latin America: a sectoral analysis. Cepal Review, 118.

Thiele, R., Nunnenkamp, P., \& Dreher, A. (2006). Sectoral aid priorities: Are donors really doing their best to achieve the millennium development goals?. Kiel Institute for World Economics Working Paper No. 1266.

Topalova, P. (2010). Factor immobility and regional impacts of trade liberalization: evidence on poverty from India. American Economic Journal: Applied Economics, 2(4), 1-41.

Tsou, M. W., Liu, J. T., \& Huang, C. J. (2006). Export activity, firm size and wage structure: evidence from Taiwanese manufacturing firms. Asian Economic Journal, 20(4), 333-354.

Turco, A. L., \& Maggioni, D. (2013). Does trade foster employment growth in emerging markets? Evidence from Turkey. World Development, 52, 1-18.

Van Biesebroeck, J. (2005). Exporting raises productivity in sub-Saharan African manufacturing firms. Journal of International economics, 67(2), 373-91.

Verhoogen, E. A. (2008). Trade, Quality Upgrading, and Wage Inequality in the Mexican Manufacturing Sector. The Quarterly Journal of Economics, 123(2), 489-530.

Wood, A. (1995). How trade hurt unskilled workers. Journal of Economic Perspectives, 9(3), 57-80. Yeyati, E. L., Panizza, U., \& Stein, E. (2007). The cyclical nature of North-South FDI flows. Journal 
of International Money and Finance, 26, 104-130.

Younsi, M., Khemili, H., \& Bechtini, M. (2019). Does foreign aid help alleviate income inequality? New evidence from African countries. International Journal of Social Economics, 46(4), 549-561.

Zheng, Z. (2020). Inflation and income inequality in a Schumpeterian economy with menu costs. Economics Letters, 186, Article 108524.

Zhu, S. C., \& Trefler, C. D. (2005). Trade and inequality in developing countries: a general equilibrium analysis. Journal of International Economics, 65(1), 21-48.

Ziliak, J. P. (1997). Efficient estimation with panel data when instruments are predetermined: an empirical comparison of moment-condition estimators. Journal of Business and Economic Statistics, 15(4), 419-431. 
Appendix 1: Definition and Source of Variables

\begin{tabular}{|c|c|c|}
\hline Variables & Definition & Sources \\
\hline WINEQ & $\begin{array}{l}\text { This is the Theil index of inequality in wages in } \\
\text { the manufacturing sector. Its values range from } \\
0 \text { to } 100 \text {, with higher values indicating a rising } \\
\text { of the wage inequality. }\end{array}$ & $\begin{array}{l}\text { The database includes information on total wages, } \\
\text { employment, capital, value added, and production } \\
\text { disaggregated at the 3-digit level of the } \\
\text { International Standard Industrial Classification } \\
\text { (ISIC) revision 3. Data used for the computation } \\
\text { of the wage inequality index includes wages and } \\
\text { salaries in the manufacturing industries classified } \\
\text { into categories based on R\&D intensities. } \\
\text { The data is sourced from the industrial statistics } \\
\text { database of the United Nations Industrial } \\
\text { Development Organization (UNIDO). }\end{array}$ \\
\hline
\end{tabular}

Author's calculation based on data extracted from the database of the OECD/DAC-CRS (Organization for Economic Cooperation and Development/Donor Assistance Committee)-Credit Reporting System (CRS). Aid for Trade data cover the following three main categories (the CRS Codes are in brackets): Aid for Trade for Economic Infrastructure, which AfTTOT for Trade (expressed in constant prices 2016, US (220), and energy generation and supply (230); Dollar). Aid for Trade for Building Productive Capacity, which includes banking and financial services (240), business and other services (250), agriculture (311), forestry (312), fishing (313), industry (321), mineral resources and mining (322), and tourism (332); and Aid for Trade policy and regulations, which includes trade policy and regulations and trade-related adjustment (331).

\begin{tabular}{|c|c|c|}
\hline AfTIND & $\begin{array}{l}\text { This is the real Gross disbursements of Aid for } \\
\text { Trade allocated to the industry sector (expressed } \\
\text { in constant prices 2016, US Dollar). }\end{array}$ & $\begin{array}{l}\text { This variable is one component of the total AfT, } \\
\text { and represents the part of AfT covering industry } \\
\text { sector (321). See OECD/DAC-CRS Database. }\end{array}$ \\
\hline AfTNONIND & $\begin{array}{l}\text { This is the real Gross disbursements of Aid for } \\
\text { Trade allocated to all other sectors than the } \\
\text { industry sector (expressed in constant prices } 2016 \text {, } \\
\text { US Dollar). }\end{array}$ & $\begin{array}{l}\text { Author's calculation based on data from the } \\
\text { OECD/DAC-CRS Database. }\end{array}$ \\
\hline GDPC & GDP per capita (constant 2010 US\$) & $\begin{array}{l}\text { World Development Indicators of the World Bank } \\
\text { (WDI). }\end{array}$ \\
\hline DTP & $\begin{array}{l}\text { This is the measure of the domestic trade policy. } \\
\text { It is the score of "trade freedom" index. The latter } \\
\text { is an important component of the Economic } \\
\text { Freedom Index. It is composite measure of the } \\
\text { absence of tariff and nontariff barriers that affect } \\
\text { imports and exports of goods and services. Higher } \\
\text { values of TP reflect lower trade barriers, that is, } \\
\text { higher trade liberalisation. Lower values of TP } \\
\text { indicate rising trade restrictive measures. }\end{array}$ & Heritage Foundation (see Miller et al., 2019) \\
\hline MTP & $\begin{array}{l}\text { Average trade policy of the rest of the world. For } \\
\text { a given country, this variable has been calculated } \\
\text { as the average trade freedom score of the rest of } \\
\text { the world. }\end{array}$ & $\begin{array}{l}\text { Author's calculation based on the "DTP" variable, } \\
\text { extracted from the Heritage Foundation. }\end{array}$ \\
\hline
\end{tabular}


Appendix 1: Continued

\begin{tabular}{|c|c|c|}
\hline Variables & Definition & Sources \\
\hline OPEN & $\begin{array}{l}\text { This is a second measure of trade openness, } \\
\text { calculated as the sum of exports and imports of } \\
\text { goods and services, as a share of GDP (expressed } \\
\text { in percentage). }\end{array}$ & WDI \\
\hline OPENSW & $\begin{array}{l}\text { This is the measure of trade openness suggested } \\
\text { by Squalli and Wilson (2011). It is calculated as } \\
\text { the measure of trade openness (the variable } \\
\text { "OPEN" previously described) adjusted by the } \\
\text { proportion of a country's trade level relative to } \\
\text { the average world trade (see Squalli and Wilson, } \\
\text { 2011: p1758). }\end{array}$ & $\begin{array}{l}\text { Authors' calculation based on data extracted from } \\
\text { the WDI }\end{array}$ \\
\hline ECI & $\begin{array}{l}\text { This is the Export Product Concentration Index. } \\
\text { It is calculated using the Herfindahl-Hirschmann } \\
\text { Index. Its values are normalized so that they range } \\
\text { between } 0 \text { and } 1 \text {. An index value closer to } 1 \\
\text { indicates a country's imports are highly concentrated } \\
\text { on a few products. On the contrary, values closer } \\
\text { to } 0 \text { reflect exports are more homogeneously } \\
\text { distributed among a series of products. }\end{array}$ & UNCTAD Database. \\
\hline EDU & $\begin{array}{l}\text { This is the measure of the education level. It is } \\
\text { calculated as the average of the gross primary } \\
\text { school enrolment rate (in percentage), secondary } \\
\text { school enrolment rate (in percentage) and tertiary } \\
\text { school enrolment rate (in percentage). }\end{array}$ & $\begin{array}{l}\text { Author's calculation based on data collected from } \\
\text { the WDI. }\end{array}$ \\
\hline MANEXP & $\begin{array}{l}\text { This is the share }(\%) \text { of total exports of } \\
\text { manufactured products in total export products. }\end{array}$ & \multirow{9}{*}{$\begin{array}{l}\text { Author's calculation based on data extracted from } \\
\text { the United Nations Conference on Trade and } \\
\text { Development (UNCTAD) Database. See online: } \\
\text { http://unctadstat.unctad.org/wds/TableViewer/table } \\
\text { View.aspx?ReportId=120 }\end{array}$} \\
\hline LABEXP & $\begin{array}{l}\text { This is the share }(\%) \text { of exports of } \\
\text { Labour-intensive and resource-intensive } \\
\text { manufactures in total export products. }\end{array}$ & \\
\hline LOWEXP & $\begin{array}{l}\text { This is the share }(\%) \text { of exports of Low-skill and } \\
\text { technology-intensive manufactures in total export } \\
\text { products. }\end{array}$ & \\
\hline MEDEXP & $\begin{array}{l}\text { This is the share }(\%) \text { of exports of Medium-skill } \\
\text { and technology-intensive manufactures in total } \\
\text { export products. }\end{array}$ & \\
\hline HIGHEXP & $\begin{array}{l}\text { This is the share }(\%) \text { of the value of exports of } \\
\text { High-skill and technology-intensive manufactures } \\
\text { in total export products. }\end{array}$ & \\
\hline MANIMP & $\begin{array}{l}\text { Share }(\%) \text { of total manufacturing imports in total } \\
\text { import products. }\end{array}$ & \\
\hline MEDHIGHIMP & $\begin{array}{l}\text { Share (\%) of Medium-skill/and High-skill and } \\
\text { technology-intensive manufactures imports in } \\
\text { total import products. }\end{array}$ & \\
\hline MACHIMP & $\begin{array}{l}\text { Share }(\%) \text { of Machinery and transport equipment } \\
\text { imports in total import products. }\end{array}$ & \\
\hline FDISTOCKGDP & $\begin{array}{l}\text { This is the measure of the share of inward Foreign } \\
\text { Direct Investment stock, in percentage of GDP. }\end{array}$ & \\
\hline
\end{tabular}


Appendix 1: Continued

\begin{tabular}{|c|c|c|}
\hline Variables & Definition & Sources \\
\hline FDISTOCKCST & $\begin{array}{l}\text { This variable represents the transformation of the } \\
\text { variable capturing the inward Foreign Direct } \\
\text { Investment stock (constant US\$ } 2010 \text { prices). The } \\
\text { variable capturing the inward FDI stock (constant } \\
\text { US\$ } 2010 \text { prices) has been calculated by } \\
\text { multiplying the FDI stock (\% of GDP) by the real } \\
\text { GDP (constant } 2010 \text { US\$) (e.g., Nagel et al., } 2015 \\
\text { and Herzer, 2011). }\end{array}$ & $\begin{array}{l}\text { Authors' calculation based on data on Foreign } \\
\text { Direct Investment stock ( } \% \text { of GDP) from the } \\
\text { UCNTAD database, and real GDP extracted from } \\
\text { the WDI. }\end{array}$ \\
\hline FDIFLOWSGDP & $\begin{array}{l}\text { This is the measure of the net Foreign Direct } \\
\text { Investment inflows, in percentage of GDP. }\end{array}$ & WDI \\
\hline FDIFLOWSCST & $\begin{array}{l}\text { The variable "FDIFLOWS" is the transformation } \\
\text { of the variable capturing inflows of Foreign Direct } \\
\text { Investment (constant US\$ } 2010 \text { prices). The } \\
\text { variable capturing the Foreign Direct Investment } \\
\text { inflows (constant US\$ } 2010 \text { prices) has been } \\
\text { calculated by multiplying the Foreign Direct } \\
\text { Investment inflows (\% of GDP) by the real GDP } \\
\text { (constant 2010 US\$) (e.g., Nagel et al., } 2015 \text { and } \\
\text { Herzer, 2011). }\end{array}$ & $\begin{array}{l}\text { Authors' calculation based on data on net Foreign } \\
\text { Direct Investment inflows (\% of GDP) from the } \\
\text { UCNTAD database, and real GDP extracted from } \\
\text { the WDI. }\end{array}$ \\
\hline
\end{tabular}

This is the variable representing the institutional and governance quality in a given country. It has been computed by extracting the first principal component (based on factor analysis) of the following six indicators of governance. These indicators include a measure of political stability and absence of violence/terrorism; the regulatory INST quality; an index of rule of law index; the government effectiveness index; the index of Voice and Accountability; and the index of Data on the components of the variable "INST" has been collected from World Bank Governance Indicators (WGI) developed by Kaufmann, Kraay and Mastruzzi (2010) and recently updated.

\section{corruption.}

Higher values of this index are associated with better governance and institutional quality, while lower values reflect worse governance and institutional quality.

This is the annual inflation rate (\%) is based on Consumer Price Index -CPI- (annual \%) where

INFL missing values has been replaced with values of Authors' calculation based on data from the WDI. the GDP Deflator (annual \%).

\section{Appendix 2: Description of the Method Used to Expand AfT Data}

We rely on AfT commitment data and adopt the approach used in Clemens et al. (2012), Thiele et al. (2006) and Selaya and Sunesen (2012) to expand AfT data to the period 1996-2016. The approach assumes that the proportion of AfT actually disbursed to sector "x" ( $\left.A f T_{x}\right)$ (for example, AfT disbursed for economic infrastructure; productive capacity building; and trade policies and regulations) during a given period is equal to the proportion of aid committed to sector $\mathrm{x}$ during this period, and is hence given by $A f T_{x}=\frac{\text { Commit }_{x}}{\sum_{x} \text { Commit }_{x}} \sum_{x} A f T_{x}$, where 
Commit $x$ stands for the amount of real AfT commitments (constant US dollar 2016 prices) to sector $\mathrm{x}$; $\sum_{x} A f T_{x}$ is the total amounts of AfT commitments and disbursements (constant US dollar 2016 prices) received during each period respectively. While there may be some concerns about the approximation of sectoral disbursements with sectoral commitments because of differences in definitions and statistical record (see Clemens et al., 2012 for more details), Odedokun (2003) and Clemens et al. (2012) have noted that this problem is likely to be small since aid disbursements and commitments (both on the aggregate and sectoral levels) are highly correlated. Using this formula and based on AfT commitments and disbursements (constant US dollar 2016 prices) extracting from the OECD/CRS database, we have calculated for each country-year, from 1996 to 2001, data on gross disbursements of AfT (including for all components of total AfT flows considered in the analysis). This dataset has been merged with the available dataset on OECD/CRS database over the period 2002-2016 (of the OECD/CRS database), and we finally get our dataset of 65 countries over the period 1996-2016.

Appendix 3a: Standard Descriptive Statistics on the Unstandardized Variables Used in the Analysis

\begin{tabular}{|c|c|c|c|c|c|}
\hline Variable & Observations & Mean & Standard deviation & Minimum & Maximum \\
\hline WINEQ & 325 & 22.92922 & 11.57086 & .001837 & 100 \\
\hline AfTTOT & 427 & $2.98 \mathrm{e}+08$ & $4.96 \mathrm{e}+08$ & 375209.3 & $3.65 \mathrm{e}+09$ \\
\hline AfTIND & 423 & $1.60 \mathrm{e}+07$ & $3.41 \mathrm{e}+07$ & 1640 & $3.49 \mathrm{e}+08$ \\
\hline AfTNONIND & 423 & $2.84 \mathrm{e}+08$ & $4.74 \mathrm{e}+08$ & 206329.4 & $3.51 \mathrm{e}+09$ \\
\hline EDU & 445 & 71.653 & 18.794 & 4.669 & 111.962 \\
\hline GDPC & 453 & 4966.359 & 5120.720 & 222.965 & 25027.410 \\
\hline INFL & 452 & 8.494 & 12.074 & -2.724 & 174.478 \\
\hline DTP & 432 & 68.057 & 12.386 & 13.467 & 88.533 \\
\hline OPEN & 434 & 81.177 & 42.511 & 0.175 & 317.364 \\
\hline OPENSW & 434 & 0.003 & 0.006 & 0.000 & 0.044 \\
\hline FDISTOCKCST & 449 & $4.60 \mathrm{e}+12$ & $1.03 \mathrm{e}+13$ & $1.38 \mathrm{e}+09$ & $9.88 \mathrm{e}+13$ \\
\hline FDISTOCKGDP & 451 & 42.524 & 137.647 & 0.380 & 1708.986 \\
\hline FDIFLOWSCST & 450 & $6.48 \mathrm{e}+11$ & $2.17 \mathrm{e}+12$ & $-8.95 \mathrm{e}+11$ & $2.30 \mathrm{e}+13$ \\
\hline FDIFLOWSGDP & 450 & 5.213 & 19.383 & -11.196 & 387.716 \\
\hline MANEXP & 451 & 42.211 & 28.325 & 0.888 & 93.878 \\
\hline LABEXP & 451 & 15.784 & 17.655 & 0.072 & 86.920 \\
\hline LOWEXP & 451 & 5.163 & 6.512 & 0.026 & 43.244 \\
\hline MEDEXP & 451 & 8.414 & 9.147 & 0.038 & 45.388 \\
\hline HIGHEXP & 451 & 12.850 & 13.881 & 0.406 & 68.966 \\
\hline $\mathrm{ECI}$ & 451 & 0.300 & 0.181 & 0.071 & 0.874 \\
\hline MANIMP & 451 & 64.564 & 10.442 & 36.847 & 87.850 \\
\hline MEDHIGHIMP & 451 & 44.845 & 10.895 & 23.344 & 73.511 \\
\hline MACHIMP & 451 & 30.151 & 9.494 & 11.857 & 61.753 \\
\hline MTP & 455 & 68.134 & 6.135 & 58.487 & 75.434 \\
\hline
\end{tabular}


Appendix 3b: Standard Descriptive Statistics on the Standardized Variables Used in the Analysis

\begin{tabular}{|c|c|c|c|c|c|}
\hline Variable & Observations & Mean & Standard deviation & Minimum & Maximum \\
\hline WINEQ & 325 & $5.88 \mathrm{e}-07$ & 0.896 & -2.129 & 2.102 \\
\hline AfTTOT & 427 & $7.42 \mathrm{e}-09$ & 0.922 & -1.604 & 2.226 \\
\hline AfTIND & 423 & $4.62 \mathrm{e}-09$ & 0.921 & -1.828 & 2.258 \\
\hline AfTNONIND & 423 & $4.55 \mathrm{e}-09$ & 0.921 & -1.569 & 2.233 \\
\hline EDU & 445 & $3.79 \mathrm{e}-08$ & 0.925 & -2.203 & 1.974 \\
\hline GDPC & 453 & $1.26 \mathrm{e}-08$ & 0.927 & -2.097 & 1.943 \\
\hline INFL & 452 & $-1.77 \mathrm{e}-09$ & 0.926 & -2.177 & 2.255 \\
\hline DTP & 432 & $-1.86 \mathrm{e}-08$ & 0.924 & -2.040 & 1.810 \\
\hline OPEN & 434 & $1.97 \mathrm{e}-08$ & 0.924 & -2.052 & 1.996 \\
\hline OPENSW & 434 & $2.66 \mathrm{e}-08$ & 0.924 & -1.975 & 1.996 \\
\hline FDISTOCKCST & 449 & $1.17 \mathrm{e}-08$ & 0.926 & -2.001 & 2.136 \\
\hline FDISTOCKGDP & 451 & $2.77 \mathrm{e}-09$ & 0.926 & -2.118 & 2.104 \\
\hline FDIFLOWSCST & 450 & $6.17 \mathrm{e}-09$ & 0.926 & -2.008 & 2.206 \\
\hline FDIFLOWSGDP & 450 & $-8.40 \mathrm{e}-09$ & 0.926 & -2.022 & 2.214 \\
\hline MANEXP & 451 & $-6.60 e-08$ & 0.926 & -2.053 & 2.204 \\
\hline LABEXP & 451 & $8.06 \mathrm{e}-09$ & 0.926 & -2.001 & 2.248 \\
\hline LOWEXP & 451 & $-1.55 \mathrm{e}-08$ & 0.926 & -1.886 & 2.128 \\
\hline MEDEXP & 451 & $2.93 \mathrm{e}-08$ & 0.926 & -2.253 & 2.216 \\
\hline HIGHEXP & 451 & $-3.93 e-08$ & 0.926 & -2.061 & 2.135 \\
\hline ECI & 451 & $1.98 \mathrm{e}-08$ & 0.926 & -2.124 & 2.197 \\
\hline MANIMP & 451 & $-7.11 \mathrm{e}-10$ & 0.926 & -2.061 & 2.181 \\
\hline MEDHIGHIMP & 451 & $-7.97 \mathrm{e}-09$ & 0.926 & -1.988 & 2.180 \\
\hline MACHIMP & 451 & $6.43 \mathrm{e}-09$ & 0.926 & -1.995 & 2.090 \\
\hline MTP & 455 & $-2.13 \mathrm{e}-08$ & 0.927 & -1.448 & 1.083 \\
\hline
\end{tabular}

Appendix 4: List of Countries Used in the Full Sample

\begin{tabular}{ccccc}
\hline & \multicolumn{4}{c}{ Full sample } \\
\hline Afghanistan & Colombia & Korea, Rep. & Montenegro & Serbia \\
Albania & Costa Rica & Kyrgyz Republic & Morocco & Slovenia \\
Algeria & Croatia & Lesotho & Mozambique & South Africa \\
Argentina & Ecuador & Macedonia, FYR & Myanmar & Sri Lanka \\
Armenia & Egypt, Arab Rep. & Madagascar & Nepal & Tanzania \\
Azerbaijan & Fiji & Malawi & Niger & Thailand \\
Belarus & India & Malaysia & Oman & Trinidad and Tobago \\
Bolivia & Indonesia & Maldives & Pakistan & Tunisia \\
Botswana & Iran, Islamic Rep. & Malta & Panama & Turkey \\
Brazil & Jamaica & Mauritius & Papua New Guinea & Uganda \\
Burundi & Jordan & Mexico & Paraguay & Ukraine \\
Chile & Kazakhstan & Moldova & Philippines & Vietnam \\
China & Kenya & Mongolia & Senegal & Yemen, Rep. \\
\hline
\end{tabular}

